\title{
El totalitarismo financiero en el Siglo XXI como fase superior del neocolonialismo (I) (medios, discursos, muertes institucionales y otras manifestaciones en la Argentina actual)
}

Human Criminal Law and financial totalitarianism in the 21st century

Direito Penal Humano e totalitarismo financeiro no Século XXI

Le droit pénal humain et le totalitarisme financier au XXIe siècle

人类刑法与 $21 世$ 纪的金融极权主义

Fernando M. Amosa ${ }^{1}$ Universidad Católica de La Plata

Revista Derechos en Acción ISSN 2525-1678/ e-ISSN 2525-1686

Año 4/No 12 Invierno 2019 (21 junio a 20 septiembre), 246-296

DOl: https://doi.org/10.24215/25251678e307

ORCID: https://orcid.org/ 0000-0002-2706-1650

Recibido: 13/08/2019

Aprobado: 01/09/2019

Resumen: El modelo punitivo desbocado ha vuelto en una nueva fase del poder planetario identificada recientemente por Raúl Eugenio Zaffaroni como Totalitarismo Financiero. Esta forma de poder representa premisas antropológicas regresivas y la delegación de la ejecución de sus funciones ordenadoras a las fuerzas de seguridad y policiales, dando lugar a una peligrosa coerción administrativa o directa cuyo en cuyo germen descansan peligrosos discursos racistas y de segregación, todos incompatibles con el Estado Social y Democrático de Derecho, a fin de garantizar un modelo de sociedad totalizante. El poder de policía en su

Abogado (UCALP). Contacto: Fernando.amosa@gmail.com 
más primitiva forma, se hace cargo subsidiariamente de los conflictos no neutralizables por el falso ídolo del poder punitivo, produciéndose muertes institucionales, mencionándose en este trabajo - en gran parte por memoria, y no sólo como casuística funcional- a Santiago Maldonado y Rafael Nahuel. La Argentina experimenta nuevamente un ensayo de una forma planetaria de poder que acecha a los Estados Sociales y Democráticos de Derecho.

Palabras claves: Derecho Penal, Criminología Critica, Totalitarismo Financiero, Estado de Policía, Derechos Humanos, Coerción Directa Administrativa.

Abstract: The uncontrolled punitive model has returned to a new phase of planetary power recently identified by Raúl Eugenio Zaffaroni as Financial Totalitarianism. This form of power represents regressive anthropological premises and the delegation of the execution of their ordering functions to the security and police forces, giving rise to a dangerous administrative or direct coercion where dangerous racist and segregation discourses rest, all incompatible with the State Social and Democratic Law, in order to guarantee a totalizing society model.The police power in its most primitive form, takes over subsidiaries of non-neutralizable conflicts by the false idol of punitive power, resulting in institutional deaths, mentioned in this work - largely by memory, and not only as functional casuistry - to Santiago Maldonado and Rafael Nahuel.Argentina experiences again a trial of a planetary form of power that stalks the Social and Democratic States of Law

Keywords: Criminal Law, Critical Criminology, Financial Totalitarianism, Police State, Human Rights.

Resumo: 0 modelo punitivo excessivo retornou em uma nova fase de poder planetário recentemente identificada por Raúl Eugenio Zaffaroni como Totalitarismo Financeiro. Esta forma de poder representa premissas antropológicas regressivas e a delegação da execução de suas funções de ordenação às forças de segurança e policiais, dando origem a uma perigosa coerção administrativa ou direta em cujo germe descansam perigosos discursos de racismo e segregação, todos incompatíveis com o Estado Social e Democrático de Direito, a fim de garantir um modelo de sociedade totalizante. 0 poder policial na sua forma mais primitiva, assume subsidiariamente os conflitos não neutralizáveis pelo falso ídolo 
do poder punitivo, ocorrendo mortes institucionais, mencionado neste trabalho - em grande parte por memória, e não só como casuística funcional - a Santiago Maldonado e Rafael Nahuel. A Argentina experimenta novamente um ensaio de uma forma planetária de poder que persegue os Estados Sociais e Democráticos de Direito.

Palavras-chave: Direito Penal, Criminologia Crítica, Totalitarismo Financeiro, Estado Policial, Direitos Humanos, Coerção Direta Administrativa.

Résumé: Le modèle punitif effréné correspond à une nouvelle phase du pouvoir planétaire récemment identifiée par Raúl Eugenio Zaffaroni comme un Totalitarisme Financier. Cette forme de pouvoir représente des prémisses anthropologiques régressives et la délégation de l'exécution de ses fonctions régulatrices aux forces de sécurité et de police, donnant lieu à une dangereuse coercition administrative ou directe, où sommeillent de dangereux discours racistes et ségrégationnistes incompatibles avec un Etat de droit social et démocratique, afin de garantir un modèle de société totalitaire. Le pouvoir policier, dans sa forme la plus primitive, se charge subsidiairement de conflits non neutralisables par la fausse idole du pouvoir punitif, entraînant des morts institutionnels, mentionnés dans cet ouvrage - en grande partie pour la mémoire, et pas seulement en tant que casuistique fonctionnelle - Santiago Maldonado et Rafael Nahuel. L'Argentine fait encore une fois l'expérience d'une forme de pouvoir planétaire qui traque les États de droit sociaux et démocratiques.

Mot-clés: Droit pénal, criminologie critique, totalitarisme financier, État policier, droits de I'homme, coercition administrative directe.

摘要:失控的惩罚模式已经回归到最近由劳尔·欧金尼奥.扎法罗尼 (RaúlEugenioZaffaroni) 确定为金融极权主义的新阶段。这种形 式的权力代表着倒退的人类学前提, 并将其命令功能的执行权下放 给安全部队和警察部队, 导致危险的行政或直接胁迫, 其危险的种族 主义和种族隔离的言论得以休息,这一切都与社会和民主法治国家, 以保证社会全面化的模式. 警察权力以其最原始的形式, 通过惩罚权 力的虚假偶像接管不可中和的冲突的子公司, 导致机构死亡, 在这项 工作中提到. 主要是通过记忆, 而不仅仅是作为功能性的诡计 - 到 Santiago Maldonado和Rafael Nahuel. 阿根廷再次经历了对社会 和民主法治国家的一种行星式权力的审判

关键字: 刑法,批判犯罪学,金融极权主义, 警察国家,人权,行政直接胁迫. 


\title{
I. Introducción. Algunos asuntos preliminares...
}

\author{
El presente trabajo tiene como objetivo exponer algunas \\ notas que perfilan a un particular fenómeno planetario que \\ experimenta el mundo - y con sus particularidades atravesa- \\ mos en nuestro país-, cuya caracterización debemos del Dr. Raúl \\ Eugenio Zaffaroni ${ }^{2}$, primero en lo penal y después en la crimino- \\ lógico, en un contexto internacional de totalitarismo financiero, \\ ultima personificación del fenómeno planetario del poder en sus
}

2 Lola Aniyar de Castro (Caracas, 8 de mayo de 1937-Maracaibo, 7 de diciembre de 2015) al analizar la Criminología de los Derechos Humanos, puntualmente la Criminología y el Derecho Penal críticos en América Latina, comentó que Zaffaroni se encuentra por primera vez con la Criminología en 1965 cuando en México comienza sus estudios junto al profesor Alfonso Quiroz Cuarón - quien era ya considerado padre de la criminología Mexicana-. En los años setenta toda América Latina tenía como marco referencial al positivismo: la criminología latinoamericana se movía dentro del paradigma del reduccionismo biológico. No obstante ello, Quiroz Cuarón - dice Zaffaroni- nunca adecuó su conducta a los dictados políticos de los inspiradores ideológicos de ese paradigma ni fue fanático defensor de éste. Fue, justamente esta tensión, esta contradicción, entre Política y criminología la que le permitió transitar otros caminos en búsqueda de alguna respuesta (...) tanto el maestro como el alumno tuvieron la misma urgente necesidad de investigar el tema de los crímenes masivos, como el genocidio y de poner sus instrumentos intelectuales al servicio del combate contra ellos. La diferencia puede tal vez radicar en que, mientras su maestro quedó aprisionado en la visión de la "ciencia" propia de la época, el discípulo, en los años posteriores luchando desde la política, pudo desentrañar que la Criminología y la Política iban de la mano y que no se podía hacer una criminología que no fuera política".

La criminóloga venezolana agregó que "El retorno de Zaffaroni a la dogmática no fue sin consecuencias. Zaffaroni se encaminó por la senda de una corriente realista, como es la de las estructuras lógico reales de Hans Welzel y, desde esa perspectiva, intentó luego - incluso en el Derecho Penal- establecer un puente entre la Criminología y el Derecho Penal. En tanto que en Alemania, después de la muerte de Hans Welzel, se retomó el cauce idealista 0 normativista (con Roxin y Jakobs, especialmente), Zaffaroni profundizó (y hasta radicalizó) el realismo de las estructuras lógico reales, que Welzel Ilevó a la teoría del delito, pero lo llevo a la teoría de la pena, dando así entrada a la Criminología sociológica y crítica. En otras palabras, no se trataban tan sólo de una discusión entre finalismo y causalismo en torno al concepto de acción, ni a su ubicación en la teoría del delito. Welzel propuso un realismo en la dogmática que revolucionó al Derecho Penal, aunque cayó en la trampa de la retribución al explicar la teoría de la pena. Zaffaroni, en cambio, extrajo todas las consecuencias de un realismo en la dogmática, que lo llevó a plantear una teoría negativa o agnóstica de la pena. "La Pena - dice- es un ejercicio de poder que no tiene función reparadora o restitutiva ni es coacción administrativa directa. Se trata de una coerción que impone privación de derechos 0 dolor, pero que no responde a los otros modelos de solución o prevención de conflictos. Lola Aniyar de Castro - Rodrigo Codino. Manual de Criminología Sociopolítica. Ed. EDIAR 2013. 
distintas etapas. En la actualidad el establishment ya no mantiene una relación horizontal con la política, sino que ejerce un dominio, ostentando una capacidad de desplazamiento geográfico del que carece la política. El poder financiero está logrando liberarse de toda coerción de la política local y también de la supranacional, dada la falta de fortaleza de los organismos internacionales ${ }^{3}$.

El capital productivo de posguerra permitía a los Estados de bienestar ejercer el poder de mediación entre las fuerzas de capital y del trabajo, pero hoy la realidad se encarga de mostrarnos que los Estados perdieron poder, ya que el capital financiero (corporaciones) - se encuentra libre de toda limitación después de la guerra fría- es anónimo, no se conocen sus dueños y a menudo sus fondos son pensiones, por lo que los ahorros de las clases medias pueden tranquilamente ser parte de ese capital. Estas masas anónimas son manejadas por burócratas o gerentes, cuya única función es garantizar su reproducción, careciendo de cualquier poder de negociación ya que pueden ser rápidamente desplazados y reemplazados por otro. La dinámica misma del aparato financiero hace que sus operadores acaten óptimamente sus mandatos de reproducción, y sus empleados jerarquizados van rompiendo con todo límite ético y legal, amparados por el servicio de un aparato transnacional de encubrimiento y reciclaje de beneficios ilícitos, que confunde el macro delito económico con la actividad lícita.

Ante el difícil contexto que nos toca vivir - y por decisión personal- asumo una toma de posición política en el presente trabajo, es fundamental dar curso a algunos primeros esfuerzos intelectuales orientados a comprender y ampliar el espectro de divulgación con respecto a un problema que se nos presenta - o nos disfrazan- tramposamente como una cuestión "de campanario o municipal", y en verdad esconde el paso de un poder planetario que vuelve -en una fase superior- a amenazar

3 Derecho Penal Humano. La doctrina de los juristas y el poder en el siglo XXI. Raúl Eugenio Zaffaroni. Ed. Hammurabi (2018). 
a nuestro Estado Social y Democrático de Derecho Latinoamericano y a nuestra ciudadanía real. Al respecto de la cuestión de campanario, en la "Cuestión Criminal", Zaffaroni ha dicho:

"Es indispensable escuchar lo que se habla para no quedar soliloqueando como suele pasar en el mundo académico. Y en nuestro país y en otros por los que a veces me desplazo se habla de la cuestión criminal como un problema local. Las soluciones pasan por condenar a uno u otro personaje o institución, pero siempre hablando de un problema local, nacional, provincial, a veces casi municipal

Pocos se dan cuenta de que se trata de una cuestión mundial, en la que se está jugando el meollo más profundo de la forma futura de convivencia e incluso del destino mismo de la humanidad en los próximos años, que puede no estar exento de errores fatales e irreversibles.

Si nos quedamos en el plano del análisis local perdemos lo más profundo de la cuestión, porque miramos las piezas sin comprender las jugadas del tablero de un ajedrez macabro, en el que en definitiva se juega el destino de todos.

Cuando nos limitamos a esos juicios quedamos entrampados en Doña Rosa es claro que debe resolverse el problema de doña Rosa, pero la trampa del viejo manipulador de los festivos 90 consistía en encerrarnos en el problema de doña Rosa (...) No estamos ante fenómenos únicamente locales, nacionales o provinciales ni municipales, sino ante problemas que podemos sólo resolver en pare en esos niveles, pero que integran un entramado mundial. Insisto: si no comprendemos ese entramado siempre moveremos mal las piezas, perderemos partida tras partida y debemos hacer el mayor esfuerzo por impedirlo, porque en el fondo se juega una encrucijada civilizatoria, una opción de supervivencia, de tolerancia, de coexistencia humana" ${ }^{4}$.

Hay un juego de pulsiones: el Estado de derecho - o fundamental de derecho- debe ser el garante de la igualdad jurídica

4 “La Cuestión Criminal”. E. Raúl Zaffaroni e llustraciones de Miguel Rep. Ed. Planeta. 2011. 
inherente al respeto a la dignidad de la persona. Pero en realidad no existen ni existieron Estados de derecho tan perfectos como ofrecen los modelos o tipos ideales, ya que todo Estado de derecho en su historicidad y realidad, "es ofue un envase que encierra pigmeos mentales autoritarios, que constantemente tratan de romper la capsula jurídica que los contiene dando lugar a un permanente juego de pulsiones y contrapulsiones":

"Al Estado que pretende una sociedad incluyente, se opone el pigmeo interno jugado por un modelo de sociedad excluyente; frente al poder político que procura mayor igualdad, pulsiona el elitista que pretende una oligarquía; al modelo que desmonta la invención de enemigos y satanizados, se le contrapone el discriminador que los inventa; al que quiere repartir más máscaras de persona, lo resiste el privilegiado que las quiere retener sólo para un grupo de pigmeos; al que busca prevenir un genocidio, lo quiere neutralizar el psicópata asesino que busca practicarlo. Y, finalmente, al modelo de derecho penal humano que quiere contener el poder punitivo, se le opone el derecho penal inhumano, que busca expandirlo al infinito.

Nadie puede ser realmente aséptico y políticamente neutral en estas confrontaciones, porque entre las pulsiones que chocan, no queda espacio para la neutralidad. Quien dice serlo y realmente lo cree, es porque está atrapado en una racionalización que, en definitiva, es un grave mecanismo de huida seriamente neurótico (incluso con algunas alteraciones de la sensopercepción, que dificulta el acceso a la realidad"5.

Este poder planetario propone una regresión al Estado de Policía y Gendarme 6 a modo de dispositivo protectorio de la

\footnotetext{
5 Derecho Penal Humano. La doctrina de los juristas y el poder en el Siglo XXI. Eugenio Raúl Zaffaroni. Ed. Hammurabi (2016).

6 "Para contener el avance del totalitarismo en acto que privilegiaba discursivamente el pan y subestimaba la libertad, se ensayó en la parte más desarrollada del planeta el modelo de Estado de Bienestar, funcionó como un amortiguador hasta que se implosionó el totalitarismo de la pretendida igualdad sin libertad y ahora, el real avance ilimitado del totalitarismo corporativo de los CEOs despliega por el mundo su propio modelo de Estado totalitario que,
} 
concentración y transferencia de la renta, y nuevas formas de dominio en los Estados latinoamericanos a través de representantes locales (Ceocratas) de este orden planetario, quienes llegaron con un discurso "fácil", "cool" o "anti-política", amplificado por los medios hegemónicos de comunicación. Estamos ante un escenario obsceno con demasiada publicidad mediática de las corporaciones mundiales y su discurso único de represión indiscriminada hacia los sectores más vulnerables o descartables (cultura del descarte).

Comparto con Zaffaroni que "Toda criminología es politica. La criminalización de una conducta o de una persona siempre es un acto de poder y, por ende, un acto político, pues se concreta en actos de gobierno de la polis que responden a un poder y que se ejerce conforme a cierto marco ideológico. Cuando un ministro ordena a la policía reprimir una manifestación o probíbe hacerlo, no hace otra cosa que ejercer un poder politico, tomar una decisión política" .

Lo propio sucede con el derecho y su vida "no tiene fin ni en sus logros ni en sus fracasos. Es un unfinished, siempre en lucha, dinámico y, sobre todo, partisano, jamás neutro. No es posible ser neutral ante la negación de la dignidad bumana, y es necesario ser partisano para luchar por su avance en la historia"s.

aunque sigue con su discurso de libertad sin pan, al igual que su contrario desaparecido, está dejando sin pan ni libertad al menos de las dos terceras partes de la humanidad.

Para consolidar el modelo de sociedad con un 30\% incorporado y un $70 \%$ estructural y definitivamente excluido, renueva y refuerza en teoría la vieja idea de Estado Gendarme, cuya función se reduciría al cuidado de los límites de una supuesta selva en que cada cual trataría de alcanzar lo que pueda, pasando por sus semejantes, como si se tratase de una masa humana huyendo de un naufragio o de un incendio. El homo homini lupus, es una frase siniestra, que además es falsa, porque en la selva no rige esta ley pues de lo contrario ésta perdería su equilibrio ecológico y se destruiría y, en cuanto al lobo, parece que es el humano del lobo del lobo...". Eugenio Raúl Zaffaroni ¿Estado Gendarme o Estado fraterno? Revista Derechos en Acción - Año 3, Nº7. Otoño 2018.

7 Zaffaroni, E. Raúl, La Palabra de los Muertos Conferencias de Criminología Cautelar. p. 11. Ed. EDIAR, 2011.

8 "El derecho es lucha", Raúl Eugenio Zaffaroni https://www.pagina12.com.ar/diario/ contratapa/13-308798-2016-09-07.html 
El derecho no es neutro, cualquier pretensión de ello en tiempos siempre fue peligrosa, más aún en estos tiempos, en el que debemos seguir siendo partisanos y construyendo un proyecto de jurisprudencia que luche contra este nuevo complejo aparataje funcional a la concentración de riqueza, mortífero para los descartables - que eventualmente podemos ser la mayoría de los ciudadanos en la medida que su establecimiento va degradando en forma de aluvión a la ciudadanía-.

Este nuevo escenario nos desafía aún más con un derecho penal del enemigo que ha perdido su sentido específico porque se ha extendido a todo tipo de legislación administrativa, en donde se verifica más fácilmente la pérdida de las garantías. En la Argentina existe un Ministerio que tiene a su cargo la ejecución de una "doctrina" que primero provocó la muerte de Santiago Maldonado, y luego la de Rafael Nahuel, dos jóvenes que han sido ejecutados extrajudicialmente en democracia. Este poder se inclina por la coerción directa o administrativa, ejecutada por la policía y las fuerzas de seguridad, pero añadiéndole un discurso punitivo del "enemigo" convierte a cualquier manifestación o conflicto en un escenario potencialmente productor de algún cadáver.

En América Latina los medios de comunicación están concentrados en grandes monopolios que forman parte del capital financiero transnacional. No se exagera al pensar que los medios hegemónicos "son parte" de esta forma planetaria de poder que nos acecha, en principio por el tipo de intereses que representan, algo sencillamente verificable en su línea discursiva, y después por el volumen de su capital.

Las circunstancias dejan entrever un escenario en el que la ciudadanía resultó engañada y manipulada por los medios hegemónicos de comunicación, cuya intensiva labor facilitó el advenimiento del actual ciclo político, a través de una fuerte estigmatización de las políticas de redistribución del ingreso llevadas a cabo por los gobiernos populares - mal llamados populistas-, a los que mediante estigmas y operaciones - con unas cuantas causas judiciales de naturaleza política- asociaron con el "robo", criminalizándose, la redistribución del ingreso en la población y la universalización de 
los derechos. Proliferaron todo tipo de discursos discursos simplones, estigmatizantes por parte de los "comunistas del sentido" - al menos del sentido...no del provecho de encerrar a la gente en el sentido común-. En fin, una jefa de Estado, cuyo gobierno resultó caracterizado por una política económica orientada a la redistribución del ingreso entre la población, y garante del bienestar y la ciudadanía real de los argentinos - con todos los contratiempos que el entorno planetario que tenemos tiene- termina procesada por ser "jefa de una asociación ilícita".

Pero antes de esto, los medios hegemónicos venían allanando el camino de la Ceocracia, aplicándole el reanimador a ciertos discursos necesarios para legitimarlos y apelaron a revivir otra falacia ya existente en nuestra sociedad- muy propia del sentido común...-: "quien llega con mucho patrimonio (es rico) no necesita robar".

Este discurso mediático, es sumamente reprochable, y tenemos que ser contundentes en la ya asumida actitud de que el campo de batalla está en los medios. Los monopolios mediáticos de la región, como en general la comunicación, no se limitan a imponer un discurso único, sino que son creadores de realidad, como lo explicó formidablemente la sociología fenomenológica de Berger y Luckman hace más de medio siglo. No es casualidad que durante el kirchnerismo, los intentos de desmonopolización mediática también terminaron estigmatizados como una lesión o un "atentado" a la libertad de expresión, de prensa, etc.

El poder necesita de los medios para crear realidad, y para ello explotan y profundizan los peores prejuicios, apelando a la conocida técnica "Völkisch". En función de ello reafirman estereotipos racistas, sexistas, étnicos, clasistas, entre otros. El resultado es un fuerte debilitamiento del sentimiento de comunidad, y fomentan un verdadero fascismo mediático que estimula a la violencia so pretexto de combatirla, promueven la venganza, profundizan los prejuicios y crean chivos expiatorios mediante una cultura de la imagen televisiva. Lo que se advierte es que los medios monopólicos tienen una táctica de entreguerra perfeccionada por su capacidad tecnológica. 
La creación de la realidad por parte de los medios es muy peligrosa en nuestra región, y también es fuente de muertes. El Estado no es quien pone las etiquetas mortíferas, ya le vienen puestas a los cuerpos por parte de los medios. Tampoco los jueces son muy libres en este esquema ya que resultan muchas veces víctimas de linchamientos mediáticos, en fin resultan victimas del linchamiento penal que genera encierros de todos aquellos etiquetados por el discurso mediático, los de imágenes criminalizables ( en caso de que estén vivos) o bien de eludir en sus sentencias la responsabilidad del Estado cuando se dan las muertes institucionales que se explicaran en el presente trabajo a través del caso "Santiago Maldonado" y "Rafael Nahuel".

Esta propagación de discurso único tiene un sujeto clave que son las clases medias latinoamericanas, al sentirse amenazadas por la violencia - real o creada-, incorporan los estereotipos del "Völkisch", mediante un "proceso de internalización de los valores del discriminador por parte del discriminado (soy negro pero no azul, soy gordo pero no obeso, soy gay pero no afeminado). Esta manipulación mediática racista lleva a nuestras clases medias a atribuir todos sus males a las subalternas, esas que están socialmente cerca por debajo, y el motivo es que su "pertenencia de clase" (dado los coletazos económicos que sufren nuestros países) es mucho más precaria que la de sus equivalentes centrales - dada la depreciación del dinero, los procesos inflacionarios, la inestabilidad laboral-, en muchos sectores la diferencia social no es del todo una realidad, sino que en buena medida responde más a un deseo por diferenciarse de los excluidos y en esos casos la única diferenciación posible es el adoptar discursos de otros segmentos sociales con centralidad económica, una especie de semejanza por reproducción verbal que no es más que personas negándose a sí mismas.

Cabe agregar que lo que nos parece irracional no debe resultarnos indiferente, porque el discurso mediático excita pulsiones y emociones que el hombre moderno ha desestimado. Y creo que dejarlo relegado a una cuestión más bien digna de un espacio terapéutico es un error. Creo que este discurso 


\section{hegemónico va de la mano con un "apego patológico a la autoridad" $y$ "amor al castigo"10.}

9 Apego a la autoridad: "Si en situaciones normales, por fuera de agravios extremos de autoridad punitiva, la población de un país no ofrece resistencia a las ilusiones sacrificiales de la autoridad como a la cultura profesional y mediática que la asiste ¿a qué debe su energía esta servidumbre subjetiva? El concepto de apego patológico al discurso de autoridad puede ser de gran utilidad para conocer la resistencia a la crítica y al cambio en la manera de relacionarnos con el conflicto. No hay representación ni idea que no esté ligada a un monto de afecto o emoción; este es uno de los grandes descubrimientos del psicoanálisis para los procesos mentales tanto inconscientes como conscientes y que en las últimas décadas a la teoría política le ha sido de utilidad para la crítica ideológica de los conceptos. Las razas no existen, son una construcción al igual que la idea de nación, pero contra viento y marea estas creencias forman parte de un sentido común por el que todavía los hombres viven y se matan. No es muy diferente la situación para la ilusión sacrificial. Parece que todo lo que el proyecto de la modernidad relegara a la periferia de la vida humana por irracional (la emoción, el afecto, la pasión) ha retornado al centro de la escena, y muy mal se haría en no contar con ello, porque - como se sabe ahora- no alcanza con acuerdos discursivos para ligar creencias y motivar acciones. La identificación con creencias punitivas provendría de un apego emocional, de lo que se conoce suficiente por las poderosas mociones vindicativas que se movilizan en la respuesta sacrificial. Por el momento, parece no haber camino más prometedor que este para la comprensión de la persistencia de la ilusión sacrificial. Las investigaciones sobre el pánico moral realizada en la década del setenta del siglo pasado no subestimaron la fibra emocional que sacuden las campañas estatales de pena y orden, en tanto lo que afecta a la población como a los agentes de criminalización, pero no salen de la crítica de la ideológica tradicional

Es cierto que las ilusiones punitivas son profecías que se cumplen: si los hombres definen las situaciones como reales aunque no lo sean las situaciones son reales". La pena no salva a la sociedad de su aniquilamiento, pero basta con creerlo para levantar guillotinas y campos de concentración. Éste ha sido siempre el problema de la servidumbre subjetiva. No alcanza la denuncia de la autoridad política, académica o del monopolio mediático cuando apelan al miedo 0 al terror para justificar castigo. En el fundamento juridico - político del mito moderno de la inexorabilidad del castigo para que la sociedad exista no faltan recursos emocionales para atemorizar con la amenaza de caos, guerra de todos y venganza homicida ilimitada. Pero este conocimiento deja sin responder por qué la población cae rápidamente en la trampa de la ilusión punitiva e incluso de ella obtiene un goce sustitutivo.". Alejandro Alagia. Hacer Sufrir. Imágenes del Hombre y de la Sociedad en el Derecho Penal. Ed. EDIAR. 2013.

10 Amor al castigo: Para que la sociedad viva alguien tiene que padecer es el lema de la creencia sacrificial heredada de la sociedad salvaje masificada en la sociedad punitiva. De no existir alguna fuerza emocional ligada a aquella creencia, no podría seguirle tampoco un beneficio de la misma naturaleza que haga posible la persistencia de la solución punitiva en la vida humana. El psicoanálisis detectó una pulsión de muerte que trabaja muda en la vida anímica para la autodestrucción y la agresividad, de la que se logra una ganancia de placer y cuyo agente es el ideal de yo, herencia de una figura de autoridad siempre ambivalente, 


\section{El caso argentino}

En el caso Argentino esta fase superior del neocolonialismo o colonialismo financiero transnacional- , encontró condiciones sociológicas proclives: un grupo de serviles CEOs, empresarios y otros ciudadanos adoradores de las ventajas de este fenómeno mundial, por un lado, y por el otro se supo que hay practicantes del "offshortismo", una no ya tan novedosa forma de criminalidad económica, de la que poco se habla por los medios de comunicación, probablemente no sólo por quienes resultan ser la variable de impacto de la práctica (El Estado, los ciudadanos, y los sectores más vulnerables), sin descontar que de que quienes la practican provienen de los más altos sectores beneficiados por esta auténtica geografía del dinero secreto).

Pero lo cierto es que ni bien asciende Cambiemos al gobierno se conoció el escándalo de las Sociedades off shore por los "Panamá Papers", en los que figura el Presidente de la Nación Argentina Mauricio Macri11 ${ }^{11}$ algunos de sus familiares y

amada y hostil. Se vuelve sobre el goce sustitutivo que ofrece el trato punitivo porque allí puede encontrarse una razón de la aparente fatalidad de respuesta sacrificial en la vida social. No se trata de un goce cualquiera. Su particularidad está dada porque es un beneficio que ofrece la autoridad; no es material, sino subjetivo con efectos reales, como hace el ideal de yo (inconsciente) con la necesidad autopunitiva para encontrarle al yo un bienestar en el padecimiento (...) De cualquier modo, ese apego emocional con una instancia castigadora interna de la que se obtiene un goce, no podría dejar de influir en la vida del hombre sino como un poderoso entrenamiento para naturalizar ilusiones sustitutivas que parten de las figuras de autoridad del mundo exterior. Alejandro Alagia. Hacer Sufrir. Imágenes del Hombre y de la Sociedad en el Derecho Penal. Ed. EDIAR. 2013.

11 De los Panamá Papers, surgió que el presidente de Argentina Mauricio Macri fue director en las sociedades: Fleg Trading Ltd, registrada en las islas Bahamas desde 1998 y con funcionamiento hasta 2009. En este contexto y aunque no forma parte de los documentos filtrados porque no se fundó con ayuda de Mosseck Fonseca, apareció una segunda empresa vinculada al presidente Macri, Kagemusha SA, integrada en mayo de 1981 y que todavía está activa según el Registro Público de Panamá (http://www.perfil.com/politica/Mauricio-Macriaparece-como-director-una-segunda-empresa-offshore-20160404-0029.html)

El 7 de abril, el fiscal Federico Delgado decidió impulsar la imputación penal contra el presidente Mauricio Macri por presunta "omisión maliciosa" en su declaración jurada, a raíz de la denuncia realizada por el diputado del Frente para la Victoria Darío Martínez que se basa 
allegados $^{12}$, entre otros dirigentes que comparten este espacio político $^{13}$.

Las sociedades off shore, son personas jurídicas constituidas en guaridas fiscales, ubicadas - por lo general- en guaridas fiscales, por eso no hay que confundirlas simplemente con una "sociedad constituida y registrada en el exterior, que suelen ser vehículos para la actividad de empresas multinacionales. En las off shore los accionistas extranjeros brillan por su ausencia o son simples testaferros que viajan de ida y de vuelta para firmar algún documento. No hay allí inversiones genuinas que aporten

en los documentos filtrados. La causa quedó a cargo del juez Sebastián Casanello (https:// www.pagina12.com.ar/diario/elpais/1-296502-2016-04-08.html)

12 Gianfranco Macri, hermano del presidente Mauricio Macri, poco después blanqueo 63.5 millones de dólares gracias a una ley que promovió el gobierno de su hermano, Mauricio Macri.

Mariano Macri, hermano del presidente argentino, sus cuentas fueron descubiertas cuando Alemania detectó movimientos sospechosos de presunto lavado o evasión en sus cuentas bancaria; la Fiscalía de Hamburgo reportó a Gianfranco y Mariano Macri, quienes aparecen vinculados a maniobras societarias y de dinero de las sociedades creadas en Panamá y Uruguay, en combinación con activos depositados en el banco UBS Deutschland. Estos hechos fueron denunciados por varios dirigentes políticos

El fallecido, Franco Macri, padre del presidente argentino, resultó investigado por el fiscal federal Federico Delgado por presunto lavado de dinero.

La oposición pidió investigar al titular del ejecutivo desde el Congreso y reclamó la renuncia de Laura Alonso, titular designada por el presidente en la Oficina Anticorrupción, quien habría defendido el uso de cuentas en paraísos fiscales por parte de Macri Luego de realizar esta defensa, Alonso fue criticada por distintos dirigentes, afirmando que debería ser la primera en exigir transparencia por parte de los servidores públicos. La diputada Margarita Stolbizer denunció que la Oficina Anticorrupción «confunde sus competencias y se convierte en la oficina de defensa de funcionarios y sus secretos». En tanto la vicepresidenta argentina defendió al presidente implicado, autocalificándose como "talibán de la transparencia» (https://www.radioformula.com.mx/noticias/mundo/20160404/defiende-vicepresidenta-amacri-por-escandalo-de-papeles-de-panama/).

13 Waldo Wolff (Diputado Nacional de Cambiemos, Daniel Ivoskus (diputado bonaerense de Cambiemos)

Gerónimo Venegas (fallecido ex dirigente sindical afín al macrismo), María Sol Ascónape, esposa del Secretario General de la Presidencia Fernando de Andreis), Claudio Avruj (Secretario de Derechos Humanos de la Nación). Se suma a la lista negra, el actual Intendente de Lanús y ex ministro de Hacienda de la Ciudad Autonóma de Buenos Aires durante el Gobierno de Macri, el Contador Héctor Grindetti. 
al crecimiento del país y si, en cambio una metodología incorporada como práctica común por los ciudadanos argentinos de privilegiada situación económica que tienden el velo de una sociedad off shore para ocultar su identidad. Sería ingenuo no asociar esas conductas con la imposibilidad de sus autores de demostrar el origen de los fondos y el objetivo de eludir obligaciones con terceros, y en especial con el Fisco.

Se ignora cuantas propiedades, fincas, campos o estancias se encuentran a nombre de las sociedades off shore - aunque no son pocos-, no sólo en la Provincia de Buenos Aires, sino en el resto del país, en especial en la Patagonia ${ }^{14}$.

La composición y praxis de los principales miembros del gobierno de Cambiemos en la República Argentina, nos coloca ante personas que llevan a cabo operatorias típicas de los beneficiarios de la concentración de la renta, ello sumado a los datos del presente y al mal momento que atraviesa el país, me ahorra de palabras para decir a qué modelo de sociedad apuntan, asimismo de las garantías punitivas de dicho proyecto hegemónico representada por el discurso de la Ministra Patricia Bullrich.

La actualidad evidencia un fuerte sesgo punitivo que da apoyatura a un proyecto hegemónico de que se sostiene desde la violencia económica que atenta contra la ciudadanía real, mediante pulsiones regresivas en la redistribución del ingreso, con la consecuente transferencia de la renta a los sectores concentrados de la economía, con Ministros que colocan el ejercicio pleno de los derechos no como una actividad que debe garantizar el Estado, sino como un problema con "costos de financiación", no como una realidad, sino como una especie de herencia con beneficio de inventario en la que el gobierno actual se excusa - permanentemente y desde un principio- de asumir las responsabilidades inherentes al principio de continuidad jurídica y constitucional del Estado.

\footnotetext{
14 Ricardo A. Nissen. "Las sociedades off shore en la República Argentina". Ed. Fundación para la Investigación y Desarrollo de las Ciencias Jurídicas (2019)
} 
Otro dato preocupante - en contexto- de avance de un proyecto inhumano, se puede apreciar en los problemas de financiamiento de la actividad de la Corte Interamericana de Derechos Humanos, comunicada el 23 de Mayo de $2016^{15}$.

Para abonar preocupaciones en el año 2017 la Corte Suprema de Justicia de la Nación Argentina (con disidencia únicamente por parte del juez Carlos Maqueda) sostuvo que La Corte sostuvo que la Corte Interamericana de Derechos Humanos no puede revocar sentencias del Máximo Tribunal argentino. Una interpretación regresiva que tira por la borda importante jurisprudencia que hace a la internacionalización y control de convencionalidad de los Derechos Humanos ${ }^{16}$.

15 “....La Comisión ha realizado gestiones permanentes a lo largo de las últimas dos décadas ante los Estados miembros de la OEA para asegurar un presupuesto que permitiera trabajar de manera eficaz en el cumplimiento de su mandato. Como resultado de esas gestiones, la Asamblea General de la OEA ha aprobado varias resoluciones comprometiéndose a atender la situación, pero las mismas no se han visto reflejadas en un aumento significativo de recursos. Mientras que el Consejo de Europa destina el 41,5\% de su presupuesto a la promoción y protección de los derechos humanos, la OEA destina el 6\% de su presupuesto a la Comisión Interamericana de Derechos Humanos.

En este sentido, la Comisión Interamericana de Derechos Humanos hace un enérgico Ilamado a los Estados Miembros de la OEA a asumir su responsabilidad con el Sistema Interamericano de Derechos Humanos. La CIDH espera que la próxima Asamblea General de la OEA, a realizarse en junio, adopte una decisión histórica y trascendental, que refleje el compromiso de los Estados con la defensa de los derechos humanos en la región. Esto significa aumentar de forma radical el presupuesto del fondo regular de la OEA y asignar a la $\mathrm{CIDH}$ y al Sistema Interamericano de Derechos Humanos en general los recursos necesarios para el cumplimiento del mandato asignado por los propios Estados. Es indispensable, imperativo y urgente que los Estados efectivamente adopten una solución sustentable a este grave y crónico problema y demuestren su compromiso con el respeto y garantía a los derechos humanos con hechos y no sólo palabras.

La CIDH expresa su firme compromiso en seguir trabajando en cumplimiento de sus funciones, inspirada por el ideal expresado en la Convención Americana sobre Derechos Humanos de que "sólo puede realizarse el ideal del ser humano libre, exento del temor y de la miseria, si se crean condiciones que permitan a cada persona gozar de sus derechos económicos, sociales y culturales, tanto como de sus derechos civiles y políticos"( http://www. oas.org/es/cidh/prensa/comunicados/2016/069.asp). Puede verse también en Asociación Civil por la Igualdad y la Justicia: https://acij.org.ar/crisis-financiera-de-la-cidh-donde-estanlos-recursos-para-financiar-los-derechos/

16 https://www.cij.gov.ar/nota-24822-La-Corte-sostuvo-que-la-Corte-Interamericana-deDerechos-Humanos-no-puede-revocar-sentencias-del-M-ximo-Tribunal-argentino.html 
Con todo, es evidente que poder mundial coloca a los Estados y a los políticos en una situación de debilidad, muchos dirigentes se entregan absolutamente o ya vienen con unas cuantas instrucciones, algo absolutamente verificable en el caso argentino desde 2016, los efectos son: sociedades desiguales, un despliegue inédito de las agencias represivas del Estado, la policización y auto ocupación policial del territorio por parte del Estado argentino, para disuadir a la protesta "no naturalizable" por parte de este poder, porque no toda protesta o manifestación lo perturba y, creo que es justo hacer mención a los casos de Santiago Maldonado y Rafael Nahuel como casos paradigmas que abrieron nuevamente el problema la letalidad policial del Estado en el gobierno de Cambiemos y los discursos mortíferos que dan apoyatura a la necropolítica en Argentina, en estas perversas ejecuciones extrajudiciales que la juridicidad y la constitucionalidad ni siquiera admitirían como pena -por tratarse de muertes, ejecuciones letales extrajudiciales-.

Con todo, desarrollaré algunos puntos que intentan describir algunos asuntos que hacen a la esencia de las problemáticas introductorias, al menos para quienes pretendemos comprenderlas desde el margen latinoamericano y en la particular posición que tenemos como continente proclive a los embates colonialistas, neocolonialistas y a las distintas fases de un poder planetario que retornó desbocado.

\section{Breve genealogía del colonialismo en nuestro margen. El poder mundial Genealogía de una fase superior del Colonialismo. Del discurso Spenceriano a la Tipología Ceocrática}

El colonialismo es un fenómeno de poder planetario que lleva siglos de sistematización y dinámica. Cualquier intento de ver las cuestiones que nos aquejan como estrictamente locales es un error en el que a estas alturas no deberíamos incurrir ${ }^{17}$.

17 “La equivocada creencia de que nuestros problemas son sólo de campanario (lo que podríamos Ilamar municipalización del poder), conspira contra la urgente necesidad de un 


\section{¿Cómo se instaló la primigenia versión de este poder en nuestra región? Poder discursos y prácticas}

Desde el siglo XV, los europeos practicaron una ocupación territorial ${ }^{18}$ de nuestro continente con su población marginada, trayendo consigo además las muertes propias de la violencia de su irrupción en estas tierras, otro tanto de letalidad resultará de las infecciones y pestes que causaron la muerte de los habitantes originarios. Por supuesto, que los sobrevivientes fueron sometidos a la servidumbre (recordemos institutos como la mita y el yanaconazgo). Dado el faltante, y a fin de continuar practicando la explotación humana necesaria para emprender en estas tierras, deciden cubrir la falta de mano de obra a través del desplazamiento de esclavos africanos, aunque también utilizaron algunos asiáticos esclavizados en el Pacífico ${ }^{19}$.

Una genealogía de las fases del poder planetario nos muestra que "El colonialismo nos niega" dice Zaffaroni y tiene razón, al punto de que no faltaron personas que han afirmado que "Latinoamerica" no existe porque "no tenemos nada en común entre los latinoamericanos". Es la afirmación más radical del colonialismo: negarnos, afirmar que no somos nada. La expresión "América Latina" (impuesta por los anhelos imperiales de Napoleón III) es criticada por algunos por racista, porque deja a fuera a los negros, a los habitantes originarios de estas

replanteo correcto que sólo puede ser regional y en el contexto mundial (Raúl Eugenio Zaffaroni "El Derecho Latinoamericano en la fase superior del colonialismo". Ediciones Madres Plaza de Mayo, 2015)

18 Raúl Eugenio Zaffaroni "El Derecho Latinoamericano en la fase superior del colonialismo". Ediciones Madres Plaza de Mayo, 2015.

19 Comenta Zaffaroni que los europeos se apoderaron del mundo a partir del siglo XV. Las pestes les habían dotado de anticuerpos de los que carecían nuestros originarios y sus microbios infectaron y mataron a la mayor parte de la población local que - a diferencia de los africanos-, también carecían de microbios capaces de infectar a los colonizadores. Fue sólo a partir del Congreso de Berlín de 1885 (Convocado por Bismarck), que las potencias neocoloniales se la repartieron arbitrariamente, ocupándola en forma parecida al colonialismo originario de nuestra región, aunque sin traslados masivos de población blanca, salvo en Sudáfrica (Zaffaroni. Derecho Penal Humano. La doctrina de los juristas y el poder en el siglo XXI. Ed. Hammurabi - 2017). 
tierras, etc. Pero, se puede resignificar el término porque en definitiva - más allá de las palabras- lo que nos ocupa es el "objeto", cualquiera sea la forma de llamarlo, es decir todxs lxs que habitamos- en estas latitudes, en este margen, quienes resultamos negados, el colonialismo es en esencia negacioncita: "Para el colonialismo y sus referentes locales, no pasamos de ser un conjunto de países nuevos con una multiplicidad de culturas que nunca pueden constituir una unidad y, además demasiado nuevos, en formación" (Zaffaroni, 2015).

Independientemente de la natural tendencia negacionista del colonialismo, nos une la desgracia: el colonialismo, además de la lengua en común que tenemos los latinoamericanos somos una realidad unitaria y perfectamente reconocible que nos une y bace reconocibles a partir del conjunto de atrocidades que esta forma de poder planetario ha ejecutado en nuestras tierras.

En el pensamiento de Hegel, encontramos un discurso negador de los "más refinados". El filósofo alemán en "Filosofía de la Historia", en la cual se refiere a un "espíritu" que avanza, aunque lo que podemos verificar de su paso es el descarte de culturas a medida de que se da su "progreso", todo lo que queda en el camino y por fuera de él es "residuo", abriéndose de esta manera paso a lo que hoy llamamos "cultura del descarte", esto es aquella inculcada y practicada por el poder con respecto a los sectores marginados y desplazados por su soberbio tránsito.

A partir de "tener historia" o no "tenerla" se definía la incorporación al "Geist" (espíritu), una soberbia actitud que negaba la cultura y toda otra actividad del espíritu que no surgiera de Europa central. En este pensamiento los indios eran inferiores sin historia, los negros amorales, los árabes, mestizos y aculturales eran musulmanes fanáticos, decadentes y sensuales, los judíos estaban sumergidos en el pensamiento del servicio riguroso, los latinos nunca habían alcanzado el alto periodo germánico y los asiáticos estaban a penas más avanzados que los negros.

La tesitura Hegeliana se sirvió de discursos antecedentes, que justificaron las diferencias naturales en una hipotética 
geología inferior y la viriginidad silvestre. En esta línea la propia ilustración con Buffon, de Paw y Raynal partieron de una supuesta inferioridad de las civilizaciones amerindias, para esta línea de pensamiento América es un país en el que los animales degeneraron bastante, cuya atmosfera contribuye a aumentar el volumen y la virulencia de los insectos venenosos, y cuyo suelo por fértil que sea solo alimenta los más dañosos reptiles.

Lo cierto es que no suele citarse a Hegel cuando se realizan prédicas racistas en América Latina, porque los agentes coloniales de por aquél entonces ("elites"), por sus propias limitaciones se vieron obligados a tomar, no a los refinados argumentos de Hegel, sino a los brutos y torpes escritos de Spencer (al que veremos en detalle a continuación) que cautivaron de inmediato a estos grupos.

Encontramos en este punto el $\mathrm{ADN}$, o formas incipientes de los discursos que nos han negado. Otro tanto se puede agregar al discurso de "parche", esto es con el que se sale cuando estas hipótesis fundadas en lo jóvenes o el tiempo, que tiemblan tiemblan frente a una circunstancia colateral o de arrastre del propio colonialismo y su Geist, que terminó generando en estas tierras un sincretismo que nos convirtió en algo como "un resultado del dinamismo sincrético de expresiones culturales marginadas por las sucesivas hegemonías planetarias".

Entonces podemos decir qué somos a partir de esta sincrética afirmación, existe un "ser humano latinoamericano que se va abriendo paso en la historia en permanente resistencia al colonialismo (que le niega o retacea su dignidad de persona), en un territorio en que muchos millones de seres humanos interactúan y sincretizan sus cosmovisiones, que son expresión de todas las culturas sometidas por el colonialismo en todo el planeta".

Se pueden ensayar - con el relativismo de toda periodización $^{20}$ - tres momentos de este poder en nuestro continente:

20 Eugenio Raúl Zaffaroni. El derecho latinoamericano en la fase superior del colonialismo (2015). Ed. Madres de Plaza de Mayo. 
Desde el fin de las guerras civiles y la consolidación de los estados hasta 1910 (repúblicas oligárquicas)

En las repúblicas oligárquicas que se establecieron cuando terminaron o amainaron las sangrientas guerras civiles posteriores a la independencia, se dieron constituciones liberales sobre la base del modelo norteamericano, que prácticamente era la única constitución que tenían a mano en ese momento. Aunque lejos de realizar el principio de soberanía popular, monopolizaron la producción primaria y constituyeron unas "elites" por imitación a Europa en sus hábitos, modas, costumbres, con un gran desprecio al resto de la población -reducida a condición servil-. Argentina no fue ajena a estos procesos, un claro ejemplo estuvo en la generación del 80 , cuyo positivismo $\mathrm{y}$ armas ocasionaron un despliegue genocida inédito, consagrando la patria del alambrado. Más tarde estos grupos a partir del genocidio en el que se quedarían con "el desierto" - que no era tal- se organizarían como sociedad rural, una corporación que tuvo actitudes políticas adictas a los intereses extranjeros, al punto de apoyar las peores interrupciones de los gobiernos populares. Otros ejemplos son el Porfiriato mexicano, la oligarquía de la carne enfriada argentina, el Patriciado peruano, la República Velha brasileña.

Todo poder necesita un discurso, y estas oligarquías vernáculas no abandonarían el liberalismo discursivo, pero lo deformarían de una forma bastante particular. Adoptaron, no a Hegel y su Geist, ni otras voces que se les dificultó comprender - por su complejidad-, apelaron a las aberraciones de Herbert Spencer (1820-1903), quien esbozaba un evolucionismo caracterizado por un reduccionismo biológico, legitimante de la tutela de las minorías, porque postergaba la efectiva realización del liberalismo para el momento futuro en que el pueblo estuviese educado bajo la tutoría de la oligarquía local, encargada de mejorar biológicamente a una población racialmente inferior. Esta afirmación efectuada por Zaffaroni sobre Spencer, es bien intencionadamente criticada por Gabriel Ignacio 
Anitua $^{21}$, y que de asistir razón a este último, la conclusión nos llevaría a pensar a que nuestras "elites" tenían limitaciones de comprensión importantes aún con el "discurso simplón, fácil, etc"22.

"El gran ideólogo del evolucionismo fue Herbert Spencer (1820 - 1903). Este autor hablaba de una evolución en las sociedades de un estadio primitivo hacia una mayor civilización, y por ello se denominó usualmente "darwinismo social" a este pensamiento que justificaba, debidamente manipulado, el dominio de los burgueses de Inglaterra en el orden interno y en el mundial. Es por ello que Zaffaroni le realiza muchos reproches - algunos quizás algo injustos- a quien fuera probablemente el fundador del método sociológico y con seguridad uno de los intelectuales más influyentes en el pensamiento progresista de su época. A él, antes que a Darwin, se debía la constante referencia a la "lucha por la vida" que tanto era usada para denunciar las condiciones de vida de su momento cuanto para justificar la lucha y también la imposición de los considerados "más aptos".

Pero junto a ello Spencer sostenía que tanto el individuo - base de su sociología y convicción política- como la sociedad son sistemas interdependientes, que a su vez están integrados por subsistemas que corresponden a los aspectos internos y externos de un organismo. Entre ellos un subsistema industrial o de mantenimiento económico, y otro subsistema de mecanismos de gobierno y comunicaciones. La similitud y analogía con todo tipo de organismo deja en claro su concepción biologicista de la sociedad. Para Spencer, la sociedad era un organismo pues aumentaba su masa por reproducción y al hacerlo aumentaba su complejidad, con lo que aumentaría finalmente la diferenciación de sus funciones.

21 Historias de los Pensamientos criminológicos. Gabriel Ignacio Anitua. Ed. Del Puerto (2010 $2^{\circ}$ Reimpresión).

22 En este caso estaríamos ante lo que el Maestro Zaffaroni comenta que debemos ser cautelosos con las bibliotecas, ya que algunos libros pueden golpear nuestra cabeza y dejarnos mal. 
Ello no estaba sin embargo en contra de su individualismo anarquizante, pues este organismo carecía de centro de percepción - o conciencia colectiva-, y por lo tanto el organismo social existía en función de sus miembros y no al revés, como en otro tipo organicismos mucho más peligrosos de caer en totalitarismos.

Asimismo, este autor combinaba tales teorías con un reclamo de reducción del Estado en sus intervenciones sociales, lo que agradaba a los librecambistas ingleses pero también a los trabajadores anarquistas y a todos los demás que en el Estado veían sólo represión (...) El orden social de la naturaleza no podía ni debía ser modificado ni por los hombres ni por el Estado. El Estado no debía, según él, interferir en la selección natural de los más fuertes en el mercado. Cualquier intervención a favor de los más perjudicados, sólo podría, a la larga, perjudicarlos aún más, pues impediría que desarrollen técnicas de superación y supervivencia. Así oponía críticas a las ideas socialistas con gran predicamento ya en esa época, aunque auspiciaba uniones obreras para la educación y demás progresos obtenidos desde ellos mismos.

Tal filosofía política estaba emparentada con su realización como investigador de la sociedad, y una y otras, con sus virtudes y defectos, expresiones del pensamiento de su época y que se hace bien en llamar "evolutivo". Apareció él en numerosas obras en las que Spencer sistematizaría el conocimiento sobre las instituciones culturales y sociales, y finalmente los famosos "Principios de Sociología". Si hay una constante en esas amplísimas y heterodoxas reflexiones es la de extender el principio evolutivo y aplicarlo al más extenso campo de las relaciones sociales (...) importa analizar su aplicación de los principios evolutivos a sociedades humanas - que será lo propio, desde entonces, de la "sociología"- (...) La ley de la evolución, o del progreso, es la que ha llevado a la primigenia integración de pequeñas comunidades en otras cada vez más complejas: familia, tribu, comuna, país, Estado. La forma "superior" sigue manteniendo su seno 
en la anterior, y también al problema propio de cada una de ellas que es la "homogeneidad". El salto cualitativo de la evolución se daría al producirse la diferenciación o heterogeneidad, pues con ella caen los principios de dominación y de autoridad presentes en todo ese camino que llevaría a las sociedades industriales, con estructuras descentralizadas e individualizantes".

Sin perjuicio de ello, Spencer años después se replantea su confianza en la evolución sociedades militarizadas y autoritarias hacia otras industriales y tolerantes, al final de su vida se chocaría con el aumento de las funciones estatales y la pérdida de posibilidades para el individualismo. Terminaría dando su última oposición al curso de los acontecimientos terriblemente peligroso si se aunaba a su evolucionismo organicista y elaboraría "El hombre contra el Estado" (1884) una defensa del liberalismo político y económico frente a la convergencia de la sociedad industrial con la militar. Su liberalismo era una consecuencia del evolucionismo que parecía llevar al fin del Estado por manos del liberalismo. Este liberalismo debía enfrentarse con el autoritarismo estatal y el militarismo que le dio origen. En el fondo esta obra intentaba una reivindicación de la libertad del hombre. Pero en esa obra, también mantiene la justificación científica de la aceptada creencia en la superioridad moral del hombre europeo y de clase superior - al que veía ciertamente en peligro de extinción por su afición al razonamiento ya que el sexo se opone al cerebro y cuanto más trabaja uno menos lo hace el otro-, lo que justificaría el imperialismo de base racial. En fin, evidentemente el ingeniero ferroviario nunca pudo salir de la matriz etnocentrica, racista y biologicista.

El racismo de las oligarquías vernáculas no se limitó a los pueblos originarios y a los africanos desplazados por las circunstancias antes señaladas, sino que se extendió al mestizaje, y hasta las obras como el Martin Fierro nos dan testimonio de ello.

Para abordar al mestizaje, se sirvieron de otro discurso que estaba en bandeja, una tesis de la psiquiatría francesa, "la 
teoría de la degeneración moral" de Morel - que tuvo como adepto a Bunge en Argentina- e incluso el mismo Domingo Faustino Sarmiento, haciendo eco de ello llegó a afirmar que proveníamos de un cruce de razas poco apto para la democracia (discurso vigente hoy día, cuando decimos que nuestro país está así porque la mayoría de los inmigantes son españoles e italianos "del sur", con lo que también cobra vida el ideario lombrosiano, como se puede ver estos discursos nunca se van y el colonialismo los necesita en América Latina). Así como traje en colación a Spencer, no puedo dejar que Morel sea menos y por ello veamos de qué se trata el discurso de la degeneración moral que asumió importancia cuando la corporación médica cobró relevancia a partir del uso de los peritajes en los tribunales - a partir de este momento los medios les dan difusión y asumen el dominio del discurso-. En "La Palabra de los Muertos”, Zaffaroni nos habla de Bénédict Augustin Morel:

"La degeneración mestiza: De este modo los psiquiatras y médicos legistas cobraron gran prestigio social, al tiempo que Bénédict Augustin Morel (1809-1873) inventaba la degeneración, tesis de neto corte racista, que postulaba la inconveniencia del mestizaje de las razas, debido a que la unión de filos genéticos lejanos daba por resultado seres humanos desequilibrados, no en cuanto a su inteligencia sino en cuanto a su moralidad.

Ahora resultaba que los mestizos americanos producto de la incontinencia sexual de los ibéricos y que según Hegel era el error que había decidido nuestra independencia, eran simples degenerados. Esta tesis fue acogida con beneplácito en nuestra América, porque en general los mestizos y mulatos causaban más problemas políticos que los indios y afros puros: para nuestras oligarquías, la impudicia que les llevaba a reclamar derechos era parte de su degeneración".

El discurso de la corporación médica sería clave para la policía - que no contaba con discurso-, bien se sabe que la policía era la encargada del control territorial del colonialismo, 
pero al crecer la población y la pobreza ${ }^{23}$, se implementó y adaptó la ocupación policial y el control policial a las metrópolis de los países colonizadores. La policía era una novedad en las ciudades y necesitaba de un discurso "los médicos tenían un discurso sin poder y los policías un poder sin discurso, la alianza de ambos fue lo que dio por resultado el positivismo criminológico biologicista" y con él se confirmaba que ciertas personas (pobres, vulnerables y delincuentes) eran semejantes a los salvajes y debían ser tratados de forma parecida a estos, en tanto las personas "decentes" eran biológicamente superiores, ergo inmunes al poder punitivo.

Este discurso tuvo un efecto que en nuestro continente fue bien aprovechado por los tomadores de discurso fácil, se trata de la "justicia natural de la sociedad", a la que más de un personaje de la historia le debe alguna página en los libros de historia, una estatua o busto. Mediante esta idea las clases dirigentes legitimaban su hegemonía por su superioridad biológica traducida en una mayor inteligencia. En tanto que los oligofrénicos iban cayendo en la escala social; a esto se llama sedimentación social del oligofrénico ${ }^{24}$.

Como se puede apreciar el positivismo y su reduccionismo biologicista no es sólo una cuestión penal, sino un marco de referencia ideológico que justifico el control social interno de las sociedades centrales, que en nuestro país - y por imitación a estas tuvo recepción y aplicación por parte de las oligarquías

23 Esta función policial se mantiene muy vigente, y recobra una enorme actualidad las autoridades suelen servirse de esa situación para llenar los espacios públicos de policías frente a la necesidad de venta ambulante por parte de personas inmigrantes provenientes de África - muchos corridos de sus tierras por los efectos devastadores en sus débiles Estados por parte del poder financiero que viene realizando ensayos en dichas tierras, y otra gente que vende ropa usada para subsistir que aumenta cada vez más porque Argentina indudablemente). Hace algún tiempo se escuchó a la Gobernadora de la Provincia de Buenos Aires referirse a estos problemas, y se los atribuyó casi malthusianamente al "crecimiento de la población" https:// www.ambito.com/el-desempleo-la-poblacion-y-el-malthusianismo-cambiemos-n5044873.

24 Raúl Eugenio Zaffaroni. La Palabra de los Muertos. Conferencias de Criminología Cautelar. Ed. EDIAR. 2011. 
vernáculas, dando lugar a verdaderas masacres estatales-. En nuestra región una vez instalada esta etiqueta les cabría a los "gringos degenerados" (inmigrantes europeos anarquistas, socialistas, sindicalistas y judíos). Todos estos grupos reaccionarios de inspiración francesa antidreyfusiana, xenófoba y antisemita darían lugar en la Argentina al golpe de 1930.

Desde 1910 hasta los años setenta (conformación de populismos y antipopulismos)

La reacción en contra de los disparates comentados, comienzan con la Revolución Mexicana y da lugar a los movimientos populistas (el cardenismo mexicano, el aprismo peruano, el velasquismo ecuatoriano, el varguismo brasileño, el irygoyenismo y el peronismo argentinos). Estos poderes emergentes no podían apelar al discurso liberal bastardeado por spencerianismo - ya asumido por las oligarquías- por lo que fueron hacia elementos discursivos y estético del autoritarismo europeo de entreguerras, lo cual generó la mayoría de los etiquetamientos de mala fe, es decir neonazismo, fascismo, etc. Pero la verdad es que al ser movimientos latinoamericanos no tenían el mito imperial que utilizaban los europeos.

Tampoco su objetivo fue el mismo que en Europa, esto es una alianza con sectores privilegiados para contener un avance de la ciudadanía real, por el contrario, buscaban una situación diametralmente opuesta a estos, ya que mantenían una confrontación abierta con los sectores dominantes.

El embate colonialista contra los regímenes políticos con pulsiones redistributivas del ingreso

El momento bisagra - siempre reconociendo el riesgo arbitrario de tales afirmaciones- se puede encontrar en la intervención norteamericana en Guatemala y el suicidio forzado de Vargas (1954), la violenta destitución de Perón en 1955, y otros acontecimientos en países vecinos que signaron la reacción neocolonialista contra las pulsiones redistributivas de los 
populismos regionales - que ya venían desprestigiados por la propaganda mediática-. Al igual que en nuestros días, se criminalizó la redistribución de la renta y los empresarios morales de por aquél entonces desplegaron una campaña centradas en la corrupción.

Se abrió de este modo un periodo oscuro en nuestra región y acabaron por ocupar militarmente varios países de la región con las mismas fuerzas militares de los propios Estados, como pasó en Argentina. Desataron la "guerra centroamericana", levantaron el fantasma de la Cuba comunista, y la doctrina de la seguridad nacional - proveniente del colonialismo francés en Argelia e Indochina, pero inculcada a nuestros militares mediante la "Escuela de las Américas"-. Ahora se alucinaba con una guerra entre Oriente y Occidente, y se tomaba nuevamente la teoría del partisano de Carl Schmitt, que introducía el pseudoconcepto de Guerra Sucia, básicamente la doctrina ponía el acento en que quien se oponía a la auto-ocupación territorial de las fuerzas armadas, se los podía neutralizar a costa del cualquier mal: ya conocemos las muertes por tortura y desaparición forzada. Esta doctrina resultó importada directamente desde la Francia colonialista de los años cincuenta, pero luego se difundió por América Latina en una forma muy simplificada, desde la Escuela de las Américas situada en Panamá, donde se trabajó la mente de los cuadros superiores con una especie de cruzada para salvar al occidente cristiano, algo verificable en las declaraciones de Videla, Massera y otros personajes.

\section{La "fase superior del colonialismo"}

Las desapariciones y las muertes sistematizadas a través de genocidios, generaron el coletazo final del neocolonialismo - la culminación de esta etapa coincide con el momento mundial en que acabó el ciclo expansivo de posguerra-. Zaffaroni dice que es en este momento en el que el colonialismo da paso a su fase superior, con predominancia en el poder financiero transnacional, valido del actual desarrollo formidable de la tecnología de 
la comunicación. En esta fase ya no se ocupan tanto los territorios policialmente, como en el colonialismo originario, tampoco se acude a las oligarquías vernáculas para que mantengan la población en relaciones de servidumbre, tampoco se maquina a las fuerzas armadas con doctrinas porque ya no son confiables y generan rechazo popular - aunque ahora se está buscando, por lo menos en Argentina algunos ensayos de acercamiento-.

El sujeto que hará de agente natural de cumplimiento, serán los jóvenes brillantes provenientes del sector privado, el empresariado y el ONGismo, y un nuevo sujeto llamado Ceocracia, una nueva plutocracia. Los discursos de los que se sirven, tienen un poco de todos los que someramente se repasaron, ciertamente esta forma superior también requiere de un Estado polcizado y gendarme. Esta nueva forma es caracterizada por Zaffaroni e Ílson Dias Dos Santos ${ }^{25}$, por razones de extensión tomaré algunas de las características que me parecen más salientes:

- Una acelerada concentración de riqueza crea una plutocracia mundial, un gobierno de ricos que concentran más riqueza, validos de la libre actuación de las corporaciones transnacionales (masas de dinero), que desconoce la condición de personas y su correspondiente dignidad a las personas reales, tanto humanas como no humanas (naturaleza).

- El control social punitivo de nuestra etapa, pasa por otro lado porque responde a un marco de poder planetario diferente al que generó las críticas criminológicas de la segunda mitad del siglo pasado. Este nuevo momento del poder fue facilitado por la revolución tecnológica (particularmente la comunicacional). Esto nos demanda una nueva aproximación crítica por parte de la criminología crítica.

- La diferencia sustancial del marco de poder se debe a que en los años setenta del siglo pasado se desaceleró el desarrollo económico rápido y las grandes corporaciones

25 La nueva crítica criminológica. Criminología en tiempos de totalitarismo financiero. E. Raúl Zaffaroni - Ílson días Dos Santos. Ed. EDIAR. 2019 
acabaron con las políticas keynesianas en el norte y las desarrollistas en el sur. Es por esto que los "países sedes" de las corporaciones se endeudaron sideralmente, con lo cual sus gobernantes redujeron su papel al de agentes lobistas de éstas, impotentes para imponer cualquier cambio disfuncional a ellas.

- El poder político de origen democrático se está transfiriendo a los gerentes de las corporaciones. Ellos son los actuales tomadores de decisiones, de las que tampoco pueden liberarse los gobernantes de los países sedes de éstas que pasaron a ser Estados postsoberanos, porque sus políticos no responden a la voluntad de sus votantes sino a los límites impuestos por los organismos crediticios funcionales a las corporaciones. En caso de que pretendan cumplir con la voluntad de sus votantes, se verán condicionados, o lo harán con la voluntad viciada por los medios - pertenecientes al totalitarismo financiero que condicionan a la opinión con falsedades, etiqueta y pánico moral, asumiendo el rol de los empresarios morales de la contemporaneidad para elegir gobiernos obedientes a sus intereses corporativos.

- Los pueblos pierden soberanía, concepto otrora relativizado por el surgimiento de la jurisdicción internacional, pero hoy la soberanía es degradada a un pretexto de los Estados para eludir las sanciones internacionales.

- La democracia es cada vez más formal y menos real en los Estados postsoberanos (países sedes) como en los tardocolonizados.

- El endeudamiento es el arma sideral del totalitarismo financiero.

- Focault decía que el poder no se tiene sino que se ejerce. Los Chief Executive Officers (CEO) de las corporaciones financieras le arrebataron a la política (expresión de la soberanía popular) gran parte de su capacidad de determinar conductas ajenas, para convertirse en una nueva oligarquía o plutocracia planetaria que cuesta millones de vidas 
humanas, ocultas en la realidad manipulada por los medios hegemónicos, pero como los tomadores de decisiones no ignoran esos efectos, puede decirse que son psicópatas. Su conducta se explica desde las llamadas técnicas de neutralización de valores, que otrora explicara la conducta de los rebeldes sin causa, y que más tarde se revaloró para entender la conducta de los genocidas. Esta teoría en principio fue mentada para explicar que la delincuencia está basada en justificaciones que son válidas para los delincuentes

El argumento de los autores es que la delincuencia está basada en justificaciones para la desviación que son vistas como válidas por el delincuente, pero no por el sistema legal o la sociedad en su conjunto. Estas justificaciones del comportamiento, que denominan "técnicas de neutralización" son un componente crucial de las "definiciones favorables a la violación de la ley". Es a través del aprendizaje de de las técnicas (o motivos) que el joven se convierte en delincuente, más que por tener imperativos morales, valores y actitudes opuestos a los sostenidos por la sociedad dominante. Estas técnicas de neutralización se dividen en cinco tipos: 1) La negación de la responsabilidad: En la medida en que el delincuente pueda definirse a sí mismo como carente de responsabilidad por sus acciones desviadas, la desaprobación proveniente de él o de otros reduce su influencia restrictiva ( por ejemplo "fueron las circunstancias; la sociedad me hizo así), 2)Negación del daño o de la injuria: El delincuente frecuentemente y de alguna manera incierta cree que su comportamiento no produce ningún daño a pesar de que el hecho resulte contrario a la ley (por ejemplo: no lastimé a nadie, tiene mucho más dinero, me había ofendido), 3) La negación de la víctima: incluso si el delincuente acepta la responsabilidad por sus acciones desviadas y su voluntad de admitir que estas implican un daño o injuria, su indignación moral o la de los demás puede ser neutralizada afirmando que el daño o injuria no es incorrecto a la luz de las circunstancias (por ejemplo los 
ataques a los homosexuales o a los miembros de las minorías, el vandalismo como venganza contra un funcionario, los robos a un propietario deshonesto, son daños que a los ojos del delincuente son cometidos frente a un agresor). Mediante esta sutil técnica se coloca en situación de justiciero o vengador y la víctima es transformada en un malhechor, 4) la condena de quienes condenan: El delincuente cambia el foco de atención de sus propios actos desviados al comportamiento de aquellos que desaprueban sus violaciones. Puede sostener por ejemplo que quienes lo están condenando son hipócritas, desviados disfrazados, o que están impulsados por mala fe (por ejemplo: "la policía es corrupta, los maestros son parciales, los jueces son hipócritas, el Estado es una cueva de ladrones, no está mal evadir, etc); 5) El recurso de las lealtades superiores: Los medios de control social internos o externos pueden ser neutralizados cuando sacrifican las demandas de la sociedad, en beneficio de las demandas de grupos más pequeños, a los cuales el delincuente pertenece (por ejemplo: "no podía dejar solos a mis compañeros", "no podía fallarle a la barra", "tenía que hacerle la gamba”).

Estas técnicas recobran mayor valor para leerlas en clave estatal - ya que no corresponden sólo a los rebeldes sin causa- y la emplean con mayor frecuencia quienes ejercen el poder punitivo.

Parece que en 1957 Sykes y Matza estaban analizando las masacres estatales más que las conductas rebeldes sin causa de su tiempo. Esta observación no es nueva, puesto que fue realizada por varios criminólogos, especialmente por Zaffaroni. Por lo general se la utiliza para explicar el caso de la Shoah, pero es extensible a todas las masacres.

Ya vimos la primera elaboración de las técnicas, ahora bien, si hacemos su lectura en clave de masacre estatal tenemos que hay una "negación de la responsabilidad": En las masacres se caracteriza por definir situaciones que se 
proyectan como de extrema necesidad y que son generadas por el grupo al que se pretende aniquilar. Por eso es que en las masacres el "chivo expiatorio" no puede resultar ser cualquier persona. En principio, el grupo identificado como futura víctima debe ser identificado como "poderoso", pues de lo contrario no tendría capacidad de infundir miedo (este tema juega un rol fundamental en lo acontecido con las muertes de Santiago Maldonado y Rafael Nahuel, y la RAM, desarrollado en el punto siguiente de este trabajo).

Por otra parte, se establece una "causalidad mágica", para atribuir a ellos una peligrosidad tan formidable se apela a un viejo recurso inquisitorial, que se basa en atribuir todos los males sociales a un "ellos sustancializado". Esta causalidad se fundamentará en "la urgencia".

- Ideología encubridora y su homus económicus: Los plutócratas racionalizan su poder con una ideología única autodenominada neoliberalismo, a la que pretenden naturalizar como paradigma en la economía y en las restantes ciencias humanas. En realidad, llamamos "ideología" a un sistema de ideas, pero es asunto de la crítica de las ideologías determinar en cada caso si nos acerca a una realidad (develadora) o nos aleja de ella (encubridora). Esta práctica pone en evidencia de que toda ideología demasiado reduccionista cae en un simplismo unilateral que aleja la realidad, y además, cuando se la quiere imponer como ideología única, es posible sospechar que oculta alguna pulsión totalitaria.

La antropología plutocrática responde a estos indicadores llegando al extremo de un "neoutilitarismo", inventan un ser humano cuya conducta está siempre determinada por el cálculo de costo y beneficio (en todos los aspectos de su vida). Desde este punto de vista, la supuesta racionalidad del mercado explicaría todas las conductas de los hombres y de las mujeres. La economía se tragaría a todas las ciencias sociales y de la conducta. 
- Es incompatible con una democracia plural: La premisa que toma es la de Ludwig von Mises, para quien la finalidad del ser humano es el enriquecimiento y toda crítica de privilegios obtenidos del sistema capitalista se basa en la envidia, un disparate antropológico. De esto decanta que no puede concebirse una democracia plural en la que todos los seres humanos pretendan enriquecerse sin límites. Esta ideología supone la mercantilización de todas las relaciones sociales, es decir todo tendría un precio, de modo tal que lo que no pudiese venderse o comprarse en un corto plazo, desde esta perspectiva es algo inexistente o, de existir, sería un error que debería suprimirse (efecto de que relega al mercado la valoración de las relaciones sociales, pero el mercado admite cálculos a corto plazo, y no a largo plazo).

Esta ideología pretende un control total, y tiene una visión antropológica del homus económicus reduccionista, le termina negando a la economía el carácter de ciencia social y termina siendo un simplismo monetarista.

- Se basa en una doble idolatría: Esta es una idolatría "biteista", pues tampoco puede prescindir de una fe ciega en la omnipotencia del poder punitivo, toda vez que sin él no podría imponer su modelo de exclusión social y planetaria. La idolatría biteista se percibe cuando comprendemos que el totalitarismo financiero deposita una fe ciega e inescindible en la omnipotencia de dos seres supremos: el mercado y el poder punitivo, que se retroalimentan.

\section{Sufrimiento y muertes institucionales en la Argentina. La función de Policía y de Gendarme en una nueva guerra inexistente. Las muertes en "el sur del sur"}

"La única verdad es la realidad y la única realidad en la cuestión criminal son los muertos" (E. R. Zaffaroni, La Cuestión Criminal, 2011)"

La terrible simbiosis necesaria entre el totalitarismo financiero, y sus políticos adictos que exponen los Estados a ensayos 
de este proyecto hegemónico, y el poder punitivo es innegable. Aquí debemos tener cierta inteligencia, ya que el poder punitivo selecciona conflictos para neutralizarlos y darles una relativa aceptación que termina generalmente en alguna tipificación en el Código Penal ${ }^{26}$.

Hay reclamos con una importante densidad ideológica, como sucede con el movimiento feminista, gay, antirracistas, y en general todos los grupos que luchan contra las más diversas discriminaciones.

La cuestión es que varios de esos movimientos se vuelven ciertamente aceptables para el poder punitivo, con el riesgo de que la multiplicidad de reclamos desestabilice el sistema, para que ello no suceda el poder hegemónico necesita "normalizar" los reclamos, al respecto dice Zaffaroni:

"El poder punitivo se proyecta mediáticamente en nuestros días con carácter de un ídolo omnipotente (falso Dios), capaz de resolver todos los problemas y eliminar todo lo indeseable, con sólo describirlo en un tipo (penal) $^{27}$. Esta idolatría contemporánea tiene fanáticos e integristas, incluso violentos. Nuestro antepasado cavernícola dibujaba animales de presa en las paredes y creía que con la imagen dominaba al objeto; hoy los describimos en los boletines oficiales de los Estados.

El poder hegemónico cayó prestamente en la cuenta de que esta omnipotencia idolátrica es un excelente recurso sedativo y normalizador, con capacidad de preservación del equilibrio del sistema. Por ende, lo emplea para

\footnotetext{
26 Zaffaroni ha designado a este fenómeno como "la idolatría succionadora de la protesta" (ver en Derecho Penal Humano... página 70. Ed. Hammurabi 2016)

27 La cursiva es propia. Con "tipo" hacemos referencia a la tipificación de las conductas en el Código Penal. El problema está colocar el sustrato material del delito la acción prohibida que se castiga, y crear la ilusión de que porque aparece en el Código Penal, el problema desaparece de la realidad y nunca vuelve a suceder en cuanto punible resulte. Por ejemplo: cuando se incorporaron los delitos de género o el homicidio transfóbico, con ello no se detuvieron las muertes ni mucho menos. El patriarcado y la discriminación son problemas que la ilusión del falso Dios no pudo resolver con la magia normalizadora del tipo.
} 
contener y neutralizar la pulsión liberadora de esos movimientos, lo que explica que los medios masivos de comunicación monopólicos impulsen amplias campañas punitivista como pretendidas soluciones a esas discriminaciones. Los políticos, presos de los medios, acuñan tipos penales a veces completamente inútiles y en ocasiones de efectos reales paradojales

Estos tipos como máximo sirven para mostrar algunas víctimas, a las que se limitan a otorgar públicamente esa condición, argumentando que se trata de un efecto simbólico. En realidad, suelen sacar el conflicto de su contexto y, como siempre que se sustrae un conflicto del lugar que le corresponde (salubridad, educación, economía, etcétera), para asignarle una naturaleza artificial - penal-, lejos de resolverlo lo complica.

No obstante, estas campañas punitivista tienen singular éxito entre muchas personas sinceramente luchadoras y embanderadas en esos movimientos, que suelen caer en la trampa estafatoria del punitivismo que, como en cualquier otro caso, no sólo resuelve los conflictos, sino que abre nuevos ámbitos de arbitrariedad selectiva, con su inseparable secuela de corrupción, automatización de agencias policiales y reforzamiento de la discriminación". ${ }^{28}$

Ahora bien, cuando el problema no es susceptible de normalización, los conflictos van hacia desenlaces mortíferos ${ }^{29}$. Si el conflicto o la protesta gravita directa e inmediatamente en los intereses vitales del poder (pensemos en la Patagonia y las tierras de testaferros del poder y extranjeros millonarios), lo que se genera son muertes anunciadas, con chivos expiatorios y un fenomenal despliegue mediático para difundir las técnicas

\footnotetext{
28 Derecho Penal Humano... Raúl Eugenio Zaffaroni. Ed. Hammurabi (2016).

29 "Este problema no es ajeno a la "Doctrina" de la Ministra Patricia Bullrich, quién vocifera una "doctrina" estructurada en este sentido y que habilita la letalidad policial sin observancia alguna de los deberes funcionales que tienen los mismos. El miedo y la emergencia son dos presupuestos psicológicos que las bombas mediáticas difunden a modo de presupuesto fáctico para legitimar el despliegue de la letalidad estatal.
} 
de neutralización tendientes a justificar el escenario mortífero (como en el caso de Santiago Maldonado)

Zaffaroni (1993) $)^{30}$ habló de las "muertes institucionales", sin perjuicio de abarcar otras "muertes anunciadas" (tomando el giro de García Márquez). Estas últimas son las muertes, que en forma masiva y normalizada, causa la operatividad de la violencia del sistema penal. La normalización puede responder a "acostumbramiento por su presencia" o a un sensacionalismo momentáneo que acaba en explicaciones coyunturales momentáneas o anecdóticas, pero las muertes que más llama la atención, entre otras cosas por la implicancia que el fenómeno tiene en cuanto a internalización de un derecho humano tan elemental como la vida, son aquellas cuya proyección y recepción tiene lugar por parte de los medios masivos, que las exhiben como signos de eficacia preventiva de la policía, o sea que estas muertes, lejos de causar alarma en la población, son un recurso para provocar aquiescencia o consenso.

Estas muertes dan una impresión parecida al relato de García Márquez en la novela "Crónicas de una Muerte Anunciada". Existe en ellas una pre adjudicación de roles en un proceso mortífero, es decir muertes en la que cada uno asume un rol fijado de ante mano y el mismo se desempeña hasta el acaecimiento del trágico final - esto guarda relación con la realidad social "normalizada" por la prensa diaria, y lo veremos a continuación sobre todo en el caso de Santiago Maldonado y la supresión de ciertas circunstancias en el escenario.

Dentro de las muertes anunciadas, se encuentran las “muertes institucionales" que consisten en aquellas provocadas por el personal armado de las agencias del sistema penal en el cumplimiento de sus funciones o directa relación con las mismas. El concepto comprende dos sentidos: abarca al personal que está autorizado al uso de armas o que se tolera que las use,

30 Muertes Anunciadas (1993). Ed. Temis S.A. 
por asignársele o admitirse que cumpla funciones propias de agencias armadas del sistema penal.

La letalidad de los dos casos demuestra que cuando la afectación de este derecho humano se produce por personas que forman parte de las instituciones del Estado, tiene lugar en forma reiterada, con alta frecuencia y existe un discurso que indica o genera la sospecha de que la misma está transformándose en un fenómeno estructural que forma parte del modo del ejercicio del poder que llevan a cabo las agencias del Estado, adquieren rango de problemática iushumanista prioritaria.

Al incorporar este tipo de masacre en la Criminología, se debe tener en cuenta: a) las condiciones culturales e históricas que favorecen la instalación de un mundo paranoico; b) las conductas de las agencias políticas y de los medios masivos de comunicación que señalan chivos expiatorios; c) las agencias del poder punitivo, que son sus potenciales perpetradores; d) la conducta de los posibles chivos expiatorios, esto es, su disposición para asumir el rol (los peligrosos inventables) ${ }^{31}$.

Las masacres del poder punitivo tienen la particularidad de que sus perpetradores son agentes del sistema penal, o bien extraños que actúan con indiferencia, beneplácito u omisión. Para que esto ocurra, es necesaria a instalación de un mundo paranoico que promueva una vindicación de esta carácteristica, desproporcionada frente a la autoría, frecuencia y calidad de los delitos cometidos. Es víctima de esa vindicación un "chivo expiatorio" (enemigo), al que se convierte en responsable de la amenaza y a quien se le imputan los peores crímenes, de manera que se legitime su eliminación ${ }^{32}$.

\footnotetext{
31 Remitirnos al rol de chivo expiatorio en las "técnicas de neutralización" en clave de masacre estatal.

32 A lo largo de la historia el poder punitivo tuvo tendencias a desbocarse. En Europa, en los siglos XII y XIII, es constante, su tendencia a descontrolarse en pos de combatir "enemigos". Pero desde hace ocho siglos las emergencias y los enemigos fueron cambiando, primero eran la degeneración de la raza, la sífilis, el alcohol, la droga, el comunismo internacional, hasta llegar en la actualidad con el terrorismo, al que se pueden agregar "los inmigrantes".
} 
Una vez instalado el mundo paranoico, el poder punitivo quiebra todo límite y pasa a la etapa o posibilidad de "vindicación paranoica", mediante medidas extraordinarias o excepcionales.

Zaffaroni, introdujo otro importantísimo concepto de "masacre larvada", esto es "toda señalización comunicacional de un chivo expiatorio que se agota en la pretensión de convertirlo en enemigo". Son semillas de genocidio que no son viables o van a dar en terreno no apto para su germinación, pero que con potencia germinadora y terreno fértil.

Las muertes ponen en juego discursos de los más perversos y "chivatos" delirantes, los dos casos que traigo en colación tienen un factor común, harto reiterado en el sur argentino: que "los mapuches no son Argentinos, son Chilenos, y aniquilaron al resto de los pueblos originarios" (Puntapié inicial que los convierte en potenciales víctimas de violencia o masacres estatales justificadas por el Estado mediante sus técnicas de neutralización), cualquier lectura antropológica, sociocultural y política no racista, ni etnocentrista, entiende que en primer lugar en los tiempos pre estatales no habia divisiones geopoliticas que permitan hablar de "Argentina" y "Chile" como tal, y en segundo lugar el proceso de expansión territorial de una cultura originaria puede ser tan violento - o no- como el de cualquier cultura, sólo que en el discurso dominante el permiso de la expansión y ocupación mediante la violencia lo tiene la "civilización"(los étnicamente superiores).

El trasfondo de este asunto no es más que una jerarquización entre seres superiores e inferiores, con una tónica disparatada en la que les niega a los mapuches su posición cultural, colectiva y jurídica actual constitucionalmente avalada por nuestro país desde la reforma Constitucional de 1994 y por el progresivo proceso de constitucionalización del derecho privado a partir del año $2014^{33}$.

33 Art. 75 inc. 17 de la Constitución Nacional. El inc. 22 del mismo artículo, a su vez, reconoce la jerarquía constitucional de los Tratados Internacionales sobre Derechos Humanos, así la 
No podemos dejar de lado en estos casos una lectura de las "Técnicas de neutralización" (Sykes y Matza), aunque no como lo hicieron esos autores orientándola a la delincuencia juvenil de los 50, cabe releerlas o reinterpretarlas en "clave de Estado", porque quienes ejercen el poder punitivo son quienes más las invocan, y van con ello mucho más allá de los límites de las causas de justificación o de exculpación.

Sykes y Matza consideraban "técnicas de neutralización" las siguientes: negación de la propia responsabilidad, minimización del daño inflingido, la negación de la víctima, la condena de los jueces y la apelación a lealtades superiores.

Chivos expiatorios y víctimas de la guerra inexistente

En un lapso menor de cuatro meses Santiago Maldonado y Rafael Nahuel murieron en medio de una guerra ¿Qué cuál es el factor común mortifero en ambos casos? La ocupación policial territorial practicada por el propio Estado Argentino, en una inédita expansión de comportamientos característicos de un Estado de Policía - no de ajustados a derecho, sin razonabilidad, sin proporcionalidad-. Lo diferente, las circunstancias de tiempo, lugar y forma: Santiago Maldonado sitiado, perseguido y conducido hostilmente por la Gendarmería hacia su muerte.

Declaración de las Naciones de Unidas sobre los Derechos de los Pueblos Indígenas, el Convenio sobre pueblos indígenas y tribales, etc (Pueblos Originarios y Derechos Humanos. 2011. http://www.jus.gob.ar/media/1129142/28-cartilla_pueblos_originarios.pdf). En el año 2006 con la Ley 26.160, se declaró la emergencia en materia de posesión y propiedad de las tierras que tradicionalmente ocupan las comunidades indígenas originarias del país, cuya personería jurídica haya sido inscripta en el Registro Nacional de Comunidades Indígenas u organismo provincial competente 0 aquéllas preexistentes.

Cabe destacar que a partir del fuerte proceso de constitucionalización de la normativa infra constitucional, puntualmente a partir de la Ley № 26.994 (que sanciona el Código Civil y Comercial, en el Título Preliminar se establece a través del art. 18. Derechos de las comunidades indígenas. Las comunidades indígenas reconocidas tienen derecho a la posesión y propiedad de las tierras que tradicionalmente ocupan y de aquellas otras aptas y suficientes para el desarrollo humano según lo establezca la ley, de conformidad con lo dispuesto por el artículo 75 inciso 17 de la Constitución Nacional". 
En tanto que se le dio muerte a "Rafita", en Bariloche, con un día soleado y luminoso ${ }^{34}$.

Para cualquier policización del Estado se requiere un enemigo interno, cuya construcción en el Siglo XXI, se sirve de unos cuantos sentimientos latentes en las sociedades atosigadas por los medios televisivos que preconstruyen el diseño para dar contexto a cualquier acción policial sirviéndose de las inseguridades y miedos.

Todo eso se instala a través del odio teledirigido al "otro diferente", que es lo que se conoce como "beterofobia", cuyo origen puede ser "espontáneo" - aunque siempre hay preconceptos y definiciones de esa otredad a destruir o convertir en chivo expiatorio de la sociedad- ¿Para qué sirve al poder?: En principio para desviar la atención de la ciudadanía, focalizar la peligrosidad en grupos resistencia y lograr la violencia con cierto consenso social.

La Ministra Patricia Bullrich (y el macrismo) encañonó a la Resistencia Ancestral Mapuche ${ }^{35}$ (RAM), un movimiento de reivindicación al que el discurso oficialista transformó en un grupo terrorista dispuestos a ocasionar - en forma armada- una secesión de ciertos territorios considerados para su cultura ancestrales para formar un nuevo Estado. La maquinaria propagandística del oficialismo atribuyó distintos apoyos del IRA irlandés, el ISIS hasta las FARC Colombianas - que las alturas de este conflicto ya están en etapa de desmovilización y disolución-.

En lo externo, el Gobierno Nacional, decidió "estar en el mundo", no por cumplir sus objetivos, sino por las modas discriminatorias y xenófobas, un rasgo bien arquetípico de los

34 Una nítida descripción del asunto la encontramos en "Estallidos Argentinos. Cuando se desbarata el vago orden en el que vivimos". Mario Wainfeld. 2019 Siglo XXI Editores.

35 "El ser Mapuche, significa "gente de la tierra", y como tal, su ser e identidad se asume de esa forma. El pueblo se siente hijo del entorno natural del mundo. El Mapuche no se siente dueño de la tierra sino que sabe que pertenece a ella (Secretaría de Turismo de la Municipalidad de Bariloche, en el folleto "El pueblo Mapuche". 
gobiernos de derecha argentinos, en palabras de Mario Wainfeld un "alineamiento (simiesco) con el Departamento de Estado estadounidense en la cruzada contra el terrorismo internacional'. Y en el orden interno, garantizarles a los propietarios del sur - que tiene un importante componente de propietarios que han obtenido tierras por precios irrisorios con dividendos obtenidos en sociedades constituidas en el extranjero ${ }^{36}$, cuándo no su uso mediante permisos estatales.

\section{La muerte de Santiago Maldonado}

El corte de ruta, resulta un método de protesta social usual en la Argentina desde fines del siglo XX, bastante criminalizado por los medios en la actualidad, quizá por poner en riesgo el orden al que sirven o a su construcción de la realidad funcional a las corporaciones de las que son partes y agentes reproductores de discurso. Pero se puede recordar que el método tuvo una interpretación mediática patriótica, cuando fueron las patronales agropecuarias que protestaron contra la Resolución No 125 en tiempos del Kirchnerismo.

Las clases dominantes - y las medias que se creen que son parte y buscan la imagen y semejanza desde el control remoto - se indignan frente a las manifestaciones de otros sectores de la sociedad. Una especie de expropiación social del método de protesta que resulta "moralizado" porque lo practican las patronales y los sectores dominantes afines.

Pero a diferencia de este privilegio que neutraliza cualquier valoración negativa del método durante un inverno chubutense de 2017, en el que una pequeña manifestación que no

\footnotetext{
36 En el Sur de nuestro país no sólo se dispone de tierras que para estas comunidades resultan ancestrales sino que se lo hace de la peor manera, es conocido el caso de un renombrado director de ex SIDE, durante el último gobierno radical y ex banquero, Fernando Santibáñez, oriunda de las Islas Vírgenes Británicas, para adquirir una importante finca en uno de los lugares más exclusivos de la Patagonia Argentina, San Martín de los Andes, pagando por aquella doce mil dólares operación que fue concretada por aquella compañía a los pocos meses de constituida, con capital social de solo cincuenta mil dólares estadounidenses.
} 
conturbaba la paz interior, la ministra de Seguridad Patricia Bullrich montaría su primer caso belicoso ("casus belli") utilizando a la RAM.

Un pequeño grupo de mapuches reclamaba por la liberación de Facundo Jones Huala, Lonko (líder) de la comunidad Cushamen. El hecho generó una reacción gubernamental y Pablo Noceti -Jefe de Gabinete el Ministerio de Seguridad- viajó a Bariloche para coordinar el mecanismo represivo que tendría como resultado la muerte de un joven de 28 años de edad, llamado Santiago Maldonado.

Santiago Maldonado estaba en la Patagonia poniéndole el cuerpo a sus ideales, un joven cuyas características salientes fueron la solidaridad, un pensamiento anárquico y la artesanía como modo de vida.

Santiago fue una verdadera cacería en un inédito y desproporcionado operativo de las fuerzas. Aquél $1^{\circ}$ de Agosto se perdió rastro de Santiago. Sus allegados y las redes sociales reclamaban por su aparición, pero fue sorprendente como el gobierno defendió a capa y espada a los gendarmes atacantes, la agencia policial y judicial llevaron a cabo innumerables esfuerzos y combinaron sus energías para impedir que se sepa la verdad. La conducción del asunto, a partir de que tomó entidad.

La presencia de la Ministra de Seguridad, no tuvo incidencia alguna en el esclarecimiento del asunto, sino que por el contrario se burlaron los protocolos de cualquier pesquisa originada por causas de violencia institucional que indican apartar a la fuerza sospechada, separar a sus miembros, incomunicarlos si cuadra, peritar velozmente los celulares, interrogar a los oficiales y tropa antes de que consensuen una versión común de los hechos. La ministra se dedicó a sostener a la Gendarmería, algo que declaró al decir que "no tiraría a ningún gendarme por la ventana”, y con su inacción y respuestas provocativas logró que ganen tiempo interno.

El $6^{\circ}$ de Agosto, la RAM y Santiago Maldonado - considerado parte de ella- llegaban al programa de Jorge Lanata "Periodismo 
Para Todos", quien le daría el toque final, de la mano de los "empresarios morales" - institución clásica en la teoría del etiquetamiento- que ahora experimentan una refuncionalización Ceocrática como refuerzo de este tipo de gobierno. El periodista en cuestión, dedicó el programa a la RAM y le puso la etiqueta (labbeling) como "mayor amenaza del gobierno". En su discurso denostó al pueblo Mapuche, sirviéndose de causas armadas y todas fundadas en intereses orientados a desplazarlos de sus reclamos ${ }^{37}$.

En esta situación se llega a las elecciones Primarias Abiertas Simultáneas y Obligatorias (PASO) del 13 de Agosto que arrojaron resultados favorables a Cambiemos. Las elecciones legislativas tendrían lugar el 22 de Octubre.

El 17 de Octubre el juez Lleral llamó a Sergio Maldonado - hermano de Santiago-, a los fines de que la familia del joven desaparecido y su representante legal, presenciaran un rastrillaje. La zona del mismo ya había sido transitada y los buzos estuvieron en ella tres veces, pero ese día apareció flotando el cuerpo que tiempo después sería reconocido como el de Santiago Maldonado.

La autopsia se programó con muchas precauciones y se verificó que se trataba del cuerpo de Santiago. El informe, si bien está realizado por el prestigioso Equipo Argentino de Antropología Forense (EAAF), reconocido mundialmente. Contiene muchas conclusiones conjuntas pero deja puntos sin descifrar. Santiago murió de asfixia por inmersión coadyuvada por hipotermia en el río Chubut, aunque no se pudo precisar si en

37 En Abril de este año el Fiscal Oscar Oro y la jueza Carina Estefanía, se expidieron sobre este prontuario armado: de los 96 Expedientes Judiciales, 84 no indicaban autores materiales o sospechosos. Los 12 Expedientes restantes no tenían sustento y por ello resultaron archivados.

Absolvieron a cinco miembros de la comunidad mapuche por la usurpación del predio en el que murió Santiago Maldonado https://www.infobae.com/politica/2019/03/18/ absolvieron-a-cinco-miembros-de-la-comunidad-mapuche-por-la-usurpacion-del-predio-enel-que-murio-santiago-maldonado/ 
el mismo paraje en que fue hallado el cuerpo. No fue "plantado" allí, permaneció en el agua un lapso que pudo llegar a setenta y tres días o ser más corto, acaso cincuenta y tres. Es posible - aunque no irrefutable- que la muerte haya ocurrido el $1^{\circ}$ de Agosto. No había señales de golpes ni lesiones.

La muerte se dio en un proceso que primero produjo adormecimiento de los miembros y redujo la capacidad de movimiento. Luego derivo en un desvanecimiento que termino con la sumersión. Tampoco hay precisión sobre el tiempo en que se mantuvo vivo a flote Pudieron ser minutos u horas. Aprovechando esto el gobierno y los medios orgánicos comunicaron firmemente que quedó comprobada la inexistencia de delito, y las mentiras de la familia, los organismos de derechos humanos y la prensa crítica. Pero la investigación seguía abierta.

El escándalo de las declaraciones de Elisa Carrió acerca de que había un 20\% de posibilidades de que "ese chico este en Chile, con la RIM" en Todo Noticias, entre una catarata de negacionismo y falacias vertidas directamente por medios del Gobierno ${ }^{38}$.

Pero el primer rastrillaje del 5 de Agosto, según comentarios de los testigos, el agua llegaba a la panza de los hombres rana (también el 17 de Octubre). En el expediente falta consignar cómo se hizo aquel procedimiento inmediato y cuánto duró. Comenta Mario Wainfeld que en el expediente falta consignar cómo se hizo aquel procedimiento inmediato y cuánto duro. Varias fuentes concuerdan: fue muy breve, desganado. Aún con "mala onda", si el cadáver hubiera estado flotando donde se lo encontró, "tendría" que haber sido visto. El agua es traslúcida, solo la vegetación obstaculiza una visibilidad absoluta, y la víctima

\footnotetext{
38 Los embustes del Gobierno y amplificados por sus medios orgánicos - y difundidos por sus trolls- llegaron a extremos delirantes, se escucharon noticias en las que se dijo:

Maldonado no estuvo en la ruta 40 ese día.

Un puestero de Benetton lo había matado o dejado malherido en un duelo criollo.

Que Santiago fue visto fatigado en territorio patrio, subiéndose a camiones, cortándose las rastas en una peluquería.
}

Estaba en un pueblo cuyos habitantes eran iguales a él. La cara, la barba, la mirada. Clones. 
vestía un pantalón oscuro. Los buzos, como observó Sergio Maldonado, deben moverse y tocarse entre sí para no dejar zonas sin recorrer.

Otra incógnita es por qué Santiago se metió en el río, gélido y peligroso. El juez Lleral evade ese dilema. La versión del relato oficial es que lo hizo motu proprio, sin presiones ni forzamientos de terceros - como si en vez de hacerlo en un contexto de un violento operativo practicado por Gendarmería ${ }^{39}$-, un disparate. Las primeras manifestaciones policizante del Estado por parte de Patricia Bullrich, fueron la política de Estado que ordenó cerrar el caso y sacar del foco al Presidente con una frondosa sentencia del juez Lleral.

El juez Lleral establece como motivos de la inmersión en el agua "la desesperación, la adrenalina, y la excitación naturalmente provocadas por la huida". Los extremos de "desesperación” y "persecución” no se estudian con profundidad, dejándose de lado las modalidades del operativo: la brutalidad, el uso de armas, la persecución extendida a kilómetros de la Ruta 40, lejos del corte ya olvidado. En fin, se abandonan los móviles de la desesperación. Y la reconstrucción de la escena omite/saltea la conducta de los agresores.

39 Lleral confecciona una sentencia de alta correspondencia con los anhelos del Gobierno, dada a conocer el 29 de Noviembre de 2018 y mandó a archivar el expediente. La resolución es extensa y detallada, pero no provee un croquis de ubicación de los gendarmes que corrían a la víctima y luego lo dejaron atrás. Pero es desinteresada respecto de los aspectos relativos a cómo los gendarmes corrían a la víctima y luego lo dejaron atrás. No se preocupa en pensar por qué y para qué Santiago Maldonado se arrojó al agua. Los considerandos fragmentan el suceso, suprimiendo una de las condiciones aportadas por los miembros de gendarmería para que el joven se arrojara al agua. El juez Lleral escribió: "Con certeza se puede afirmar que Santiago Andrés Maldonado, a la carrera, huyendo de la persecución de los efectivos de la Gendarmería Nacional que se encontraban efectuando un procedimiento policial ya relatado, ataviado con todas las ropas y calzados señalados y descriptos por los peritos que materializaron la correspondiente necropsia, se introdujo con vida en las frías aguas del Río Chubut en donde, pese a sus esfuerzos por respirar y mantenerse a flote, encontró su muerte a partir de la asfixia producida por el agua de río que invadió sus vías respiratorias, del entumecimiento corporal producido por la bajísima temperatura de ese medio y de la probable pérdida de conciencia". Fallo disponible: (https://www.cij.gov.ar/nota-32662-El-Juzgado-Federal-N--2-de-Rawsondict--sentencia-en-la-investigaci-n-por-el-fallecimiento-de-Santiago-Maldonado.html) 
Santiago no se arrojó a esas frías aguas por placer, ni por deporte. Lo forzó una conducta agresiva, previa y concomitante. La tipificación de una acción como delito, requiere la concurrencia de los elementos típicos. El reproche penal, la culpa, es estricta y el pragma conflictivo que presenta el escenario nos permite pensar en las siguientes conductas:

a) Pudo haber sido coaccionado de modo irresistible a arrojarse al agua. $\mathrm{O}$ haberlo hecho por intimidación por parte de los atacantes (gendarmes) pensando que evitaba un mal mayor. En este caso cabría investigar si los hechos conducen a una variante del homicidio doloso (art. 79 C.P) o preterintencional (art. 81.inc. b) C.P).

b) También se puede pensar en una hipótesis de abandono de personas (art. 106 C.P). Los gendarmes, que estaban a metros del sitio en donde se produce el hallazgo pudieron haberlo visto caer y no lo auxiliaron.

Ninguna de estas hipótesis fueron investigadas y Lleral concluyó - con cierta violencia retórica y faltando a la labor reconstructiva del hecho- que "Cuando la simplicidad de las cosas es patente, sobrevuelan los sinsabores de la especulación espuria. El ser humano no puede detener su mente y su fantasía cuando la sencillez lo alcanza. Negase a ver la realidad es materializar lo absurdo y vivir en la mentira. En el mejor de los casos, es abrazar una quimera".

\section{El asesinato de Rafael Nahuel "Rafita"}

La misma noche en que se llevaba a cabo el velatorio de Santiago Maldonado, en 25 de Mayo (su ciudad natal, en la Provincia de Buenos Aires), la Prefectura asesinó a Rafael Nahuel (de 22 años de edad). Lo llamaban "Rafita" y pertenecía al "Alto" uno de los barrios más humildes de Bariloche.

El joven tuvo una infancia y adolescencia difícil, sus orígenes eran Mapuches, y en la encrucijada que le jugó la vida, decidió tomar el mejor de los rumbos y aprendió la profesión de carpintero, empezó a construirse una casa, también tenía una novia. 
Una tía, lo introdujo a la tradición mapuche, y lo empapó en su pertenencia a partir de ello empezó a participar activamente de su cultura.

El conflicto sureño que se llevaría su vida, se dio a raíz de una ocupación en las tierras de la zona del Parque Nacional Nahuel Huapi lindera con el lago Mascardi. No hay modo de saber cuántos mapuches ocupaban, pero con razón Mario Wainfeld comenta que "no son ejército ni una repartición burocrática: ni pasan listas, ni se practican censos ${ }^{40}$ ".

Parques Nacionales planteó plantea una denuncia. En razón de ello el juez federal Gustavo Villanueva ordenó el desalojo urgente. Parece que lo azaroso del velatorio de Santiago Maldonado y la muerte de Rafita, fue parte del azar, no así el momento político porque se correspondía a la oportunidad crear "la doctrina" que justificaría en adelante la letalidad de las fuerzas de seguridad.

La Prefectura, en Argentina, es una de las fuerzas que más intensamente participó en el terrorismo de Estado en la Dictadura Argentina. Cualidad que motivó que en épocas del kirchnerismo se confié mucho más en la Gendarmería que en la Prefectura.

Los Albatros de Prefectura conforman un cuerpo bélico de élite. Entre fusileros desbocados y disparos a mansalva y gritos por parte de los mapuches que ocupaban las tierras (que no eran gritos de código castrense sino voces de las que escuchaban cosas tales como "dejen de tirar, hay mujeres y chicos, están matando gente"), fue que descendieron dos mapuches (Fausto Jones Huala y Lautaro Alejandro González) quienes descendían cargando con el cuerpo de Nahuel "Rafita", esto puso corte a la balacera y el malherido fue llevado al hospital, pero en vano porque murió.

Ante este panorama el juez Villanueva se aisló en un hotel situado a quinientos metros del teatro de operaciones, pero por

\footnotetext{
40 Mario Wainfeld. Estallidos Argentinos. Cuando se desbarata el vago orden en que vivimos. Ed. Siglo XXI. 2019.
} 
miedo o temor, nunca ingresó al predio y prefirió antes que mirar a los ojos a los mapuches, dejarse llevar por la leyenda tramada por la Casa Rosada y Lanata. Rafita había muerto por un proyectil que ingresó por el glúteo, y sus compañeros heridos lo fueron por la espalda, lo que puso en evidencia que los ocupantes se alejaban en actitud de escape y no de ataque, con lo cual la agresión de las fuerzas queda sin margen de justificación, no estaban repeliendo nada.

Nuevamente el Gobierno y sus medios orgánicos volverían al relato belicoso, en el que el enemigo era la RAM, acusada de dar curso a las hostilidades incipientes que abrieron el conflicto. En el relato los mapuches llevaban lanzas, armas de fuego y hasta máscaras antigás, fue la versión de Patricia Bullrich y la Vicepresidenta Gabriela Michetti, quien daría vuelta una de las más elementales presunciones del derecho penal diciendo que "la Prefectura actuó en defensa propia". La ininteligible Vicepresidenta de la Nación Argentina, habló con absoluto desconocimiento de que en un bomicidio indubitado, le corresponde probar a su autor atenuante y eximentes, de no poder acreditar los extremos que disminuyan la culpabilidad o demuestren que no la hubo, el sujeto activo queda sindicado como autor del delito.

La causa terminó dando una de las sentencias más bochornosas de la era macrista y el juez calificó la conducta de los prefectos como "homicidio calificado en exceso de legítima defensa", la figura más leve que podía aplicar. Comento esto sin adentrarme demasiado en el proceso, ni darle demasiado protagonismo a Leónidas Moldes, y Villanueva.

Y el fin de la historia es que a Nahuel lo enterraron en Bariloche, con el cuerpo cubierto por la bandera de la RAM y la camiseta de Boca, un final que poco tiene que ver con guerras imaginarias obrantes en la paranoia ministerializada del gobierno que parece ser un ensayo Ceocrático en la Argentina. 


\section{Conclusiones}

El modelo punitivo desbocado ha vuelto en una fase planetaria preocupante por demás, con premisas antropológicas de terribles consecuencias en nuestras vidas.

La Argentina experimenta nuevamente un ensayo perverso, que nos interpela a nuestros esfuerzos intelectuales, que deben confirmar la vocación de lucha que tiene el derecho.

En las líneas antecedentes, se torna evidente que no es un esquema cómodo y la cabal comprensión de la problemática demanda una serie de esfuerzos e incorporación de otros saberes provenientes de la historia, la filosofía, la criminología sociopolítica, la criminología crítica, etc.

Esta fase superior del poder planetario acentúa las tendencias de agresión inter especifica del homo sapiens por lo que al indagar sobre ello no vamos a encontrar simplemente respuesta en los tratados de derecho penal, o en manuales de sociología.

Los tiempos que corren nos colocan ante la consolidación de un poder hegemónico frente al cual debemos acelerar nuestro proceso crítico, y revalidar el pensamiento latinoamericano frente a estos embates.

Este poder se inclina por la coerción directa o administrativa, y se dedica a renovar la estructura de su discurso inquisitoral en razón del enemigo elegido, es decir que hoy en día podemos pensar en que todo ese volumen de conflictos no neutralizables del poder punitivo - como se dijo al principio del presente trabajo- corre riesgo de ser "muertes anunciadas", ya que a partir de las muertes, tanto de Santiago Maldonado, como la de Rafael Nahuel, se advierte que la violencia estatal pasa a legitimarse por una "nueva doctrina" (abiertamente declarada por la Ministra Patricia Bullrich), según la cual directamente quiebra la diferencia entre poder punitivo y coerción directa administrativa y toda violencia para desbaratar al enemigo se vuelve legitima por vía de "necesidad" o de "legítima defensa", un rol que le da a las agencias policiales y de seguridad una presunción favorable a la hora del disparo. 
Aunque como conocedor del derecho administrativo, entiendo que olvida la vinculación negativa, es decir "lo que no está expresamente permitido al Estado le está prohibido" - lo mismo vale para los agentes policiales y los miembros de las fuerzas de seguridad que tienen deberes funcionales que no pueden exceder-, un postulado de permisión que la Ministra parece olvidar, como otras tantas cuestiones que los miembros del actual gobierno no comprenden o no quieren comprender.

Este humilde trabajo no puede - ni pretende parecerse- a ni siquiera a algunas páginas de la Cautio Criminalis de Friedrich Spee, pero en el sí propongo avanzar hacia la construcción de saberes orientados a pensar discursos de contención que coadyuven a la acumulación necesaria para socializar la vocación a un verdadero proyecto de saber juridico - político- penal y criminológico que se proyecte cautelarmente sobre el avance de las pulsiones regresivas al Estado policial en Argentina. 